\title{
Antiquario Della Sacra Cesarea Maesta: Strada's Tasks at Court
}

\subsection{Looking for Patronage: Strada's Arrival at the Imperial Court}

\subsubsection{Pope, King or Emperor: The Choice of a Patron}

We know very little about Strada's activities immediately after his return to Germany, and we do not even know when exactly he returned. He must have visited Venice, possibly on his way up to Mantua, but more likely from there, leaving his family and his effects in the care of his relatives. In Venice he made arrangements for the printing of the two books of which he had acquired the manuscripts from Onofrio Panvinio, the Fasti et triumphi and the Epitome pontificum. By the end of 1555 the planning of this was sufficiently advanced for Strada to make a formal request for a copyright privilege, which Charles $\mathrm{V}$ granted him from Brussels on the 8th of January of 1556. Apart from the two books by Panvinio, the privilege also includes the first mention of a voluminous illustrated universal dictionary or encyclopaedia in the three classical languages, and of a new, Latin edition of Leandro Alberti's Descrittione d'Italia, which was likewise intended to be illustrated. ${ }^{1}$ This request is the first indication of Strada's ambition to set up as a publisher himself, and particularly as a publisher of books aimed at a scholarly or at least educated audience. What is particular about the books mentioned here, is that all were planned to include printed images to illustrate the text, or to add information that could not easily be conveyed in words alone. This preoccupation with visual aids and with the presentation of visual documentation became one of the Leitmotive of Strada's career from now on.

Though Strada apparently had prospered in Rome, it is clear that to realize such an ambition he needed both material and immaterial backing. Though illustrated books had already proven good sellers, this was not necessarily the case for the scholarly productions Strada had in mind. Moreover, the standard required for documentary illustration of a level acceptable to his intended audience obviously demanded the collaboration of outstanding — and therefore

1 Copyright privilege, DOC. 1556-01-08. The titles given there do not correspond exactly with the printed versions of Panvinio's books. It is not known by what means Strada presented his request. 
expensive - printmakers. It is not surprising that Strada was looking around for influential and affluent patrons, other than Hans Jakob Fugger. Though Fugger certainly would have applauded Strada's intentions, he was getting into financial trouble-largely due to the reluctance with which Charles v and Philip II satisfied their creditors - which would lead to his bankruptcy in 1564; so he could not on his own advance the sums Strada would need. As we have seen, Strada appears to have attempted to obtain permanent patronage already in Rome, and he claimed to have obtained such patronage from Popes Julius III and Marcellus II; in view of his sustained support for antiquarian studies before his election, the latter would have been particularly sensitive to Strada's proposals. The unexpected brevity of Marcellus' reign and the accession of Paul IV Carafa — unfortunate for far greater interests than Strada's — shattered such possibilities; like other aspiring scholars Strada had to look elsewhere for the protection he needed. Thus in October 1557 his own acquaintance Onofrio Panvinio, though assured of a fixed position in Cardinal Farnese's household, consulted Antonio Agustín whether he should dedicate a forthcoming book to Maximilian, Archduke of Austria and, since 1548, titular King of Bohemia, or whether it was preferable to choose Maximilian's cousin and brother-in-law, Philip II of Spain. Agustín, who coupled a sincere faith and a profound knowledge of classical Antiquity with a remarkable astuteness in more mundane matters, formulated his advice as follows:

$<$... >between these two princes I would choose the one that is at present more highly considered, and the better friend of your patron [this was Cardinal Alessandro Farnese], that is the King of Spain, even though the other is closer to the Empire; but he will be a king of chess without the help of his cousin. ${ }^{2}$

After having just failed to obtain the patronage of the Pope, it is not surprising that Strada should have thought of applying to the highest ranking secular patron of Christianity, the Emperor, or to other members of his august house, with which his own researches were so inextricably connected. It is just possible that he considered Philip II as a potential patron: at the time Philip was not merely king of England and, soon afterward (16 January 1556), of Spain, but he had not yet been ruled out as his father's successor to the Empire. Years later

2 '<... tra quelli duoi principi pigliaria quel che hora è più sublime, e più amico del Vostro patron [this was Alessandro Cardinal Farnese], idest il Re di Spagna, benchè l'altro sia più propinquo all'Imperio; ma sarà un Re di scacchi senza l'agiuto del suo nepote $<$...>>, letter dated Rome, 2 October 1557, published in AGUSTíN 1980, nr. 191, p. 277. 
Armenini remembered that Strada had commissioned a second version of the set of illuminated drawings of the Vatican Loggia for Philip II; and though this may have been a mistake, Strada at one time certainly did intend to dedicate a manuscript containing drawings of Roman consular coinage to Charles v. ${ }^{3} \mathrm{But}$ Spanish patronage might not have appealed to Strada for many reasons, and in any case employment in Spain would have deprived him from direct contact with his sources and with the international book trade that were conditions for the success of his plans.

It was, on the other hand, quite natural for Strada to think of the Austrian branch of the dynasty. It is obvious that its future superior status (after Charles' abdication in September 1556 and the subsequent transfer of the Administratio Imperii to his brother Ferdinand) greatly appealed to Strada, who thought in ceremonial and hierarchical terms. Having spent so much time in researching the history of the Roman Emperors all the way down to Charles v himself, he was attracted by the idea of making part of their entourage. He would later always sign his letters with the title Charles' successors allowed him to use: 'Antiquario della Sacra Cesarea Maestà', and insist on the privileges he thought this conferred on him. Even when describing how he enlisted Guglielmo Gonzaga's help in fleeing from the Inquisition during a visit to Mantua in 1568, he makes play with his patron's status: 'But I have taken flight in the manner of a gentleman, because it came first to me to uphold my rank, and therefore, in my quality as a servant of the first Sovereign of the world, I went to see the Duke ...' [italics mine]. In this light it is significant that after Charles' abdication Strada decided to present the numismatic manuscript he had prepared for him to his brother Ferdinand I, the new Emperor, rather than to his son and immediate heir, Philip II of Spain. ${ }^{5}$

In applying for patronage to the Austrian Habsburgs, moreover, Strada was in a position more or less to know what to expect. I do not know what strings had needed pulling for Strada in the late 1540 s to obtain access to the archival sources he needed for the research of his Epitome thesauri antiquitatum, which for the later part largely depended on ancient Imperial charters (he claimed to derive his illustrations for the medieval Emperors from the seals attached to such documents). But it certainly would have implied at least some contact with the Imperial Chancery. Through his connection with Fugger he was well

3 Armenini 1586, p. 180; the illuminated title page of Strada's ms. De consularibus numismata (ÖNB-HS, ms. 9411) depicted Charles v's famous device of the Pillars of Hercules, which was pasted over with a strip of marbled paper when Strada presented it to Ferdinand I.

4 DOC. 1568-oo-0o: 'Ma la mia fuga è stato da gentilhuomo, perchè prima mi volsi valer del grado mio, et, come servidor del primo Signore del mondo, andai a parlare al Ducha<...>'.

5 Discussed below, Ch. 4.2. 


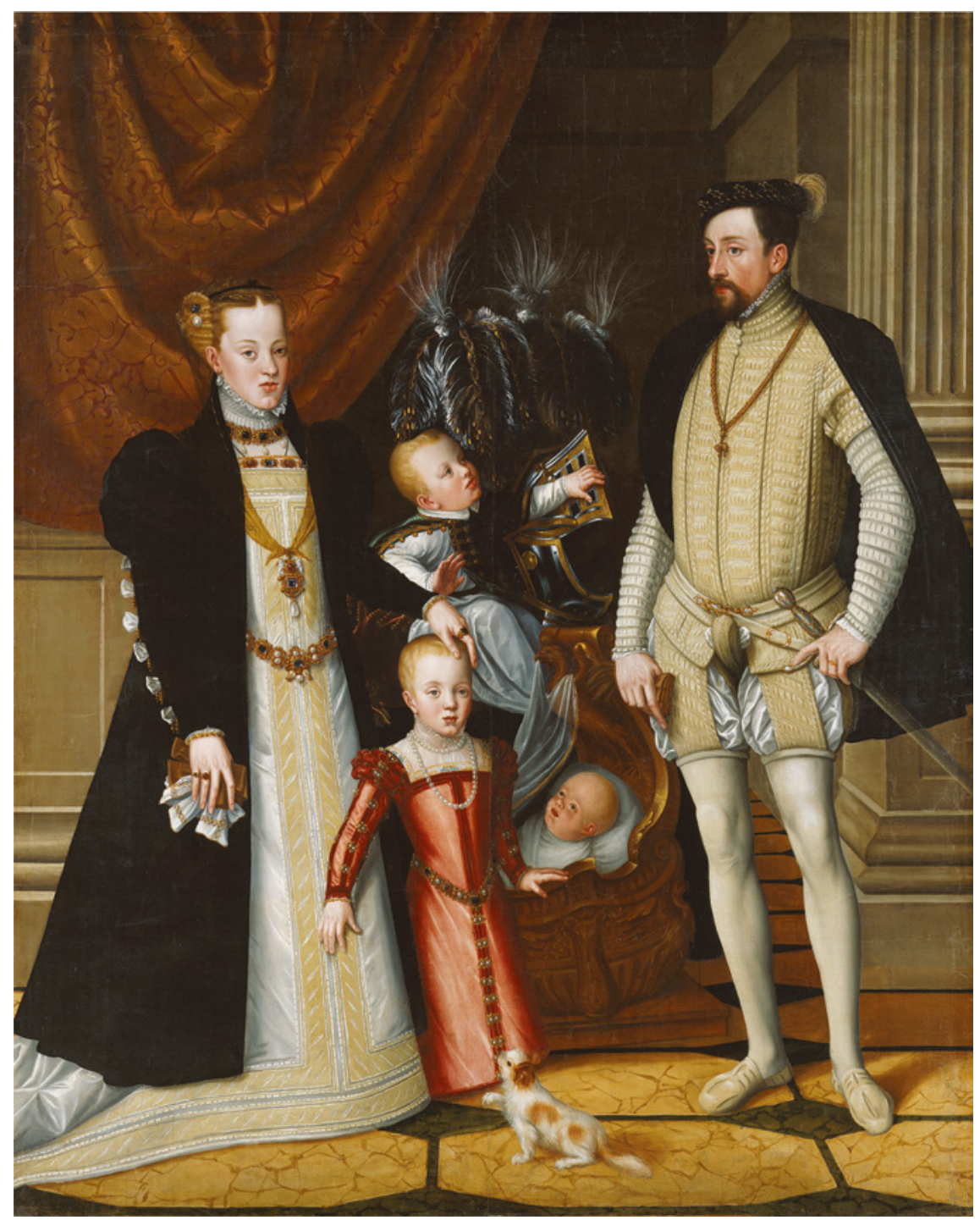

FIGURES 4.1-4.3 Archduke Maximilian, King of Bohemia (with his wife and their three eldest children), his brother Archduke Ferdinand, and their father Emperor Ferdinand I, in paintings respectively attributed to Giuseppe Arcimboldo, Francesco Terzio, and Hans Bocksberger the Elder; all Vienna, Kunsthistorisches Museum.

aware of the position and interests of Ferdinand I and at least his two elder sons, the Archdukes Maximilian and Ferdinand [Figs. 4.1-4.3]. Though Fugger was not as intimate with the Habsburgs as he was with the young Duke Albrecht $\mathrm{v}$ of Bavaria, as the principal member of a family so closely linked to 

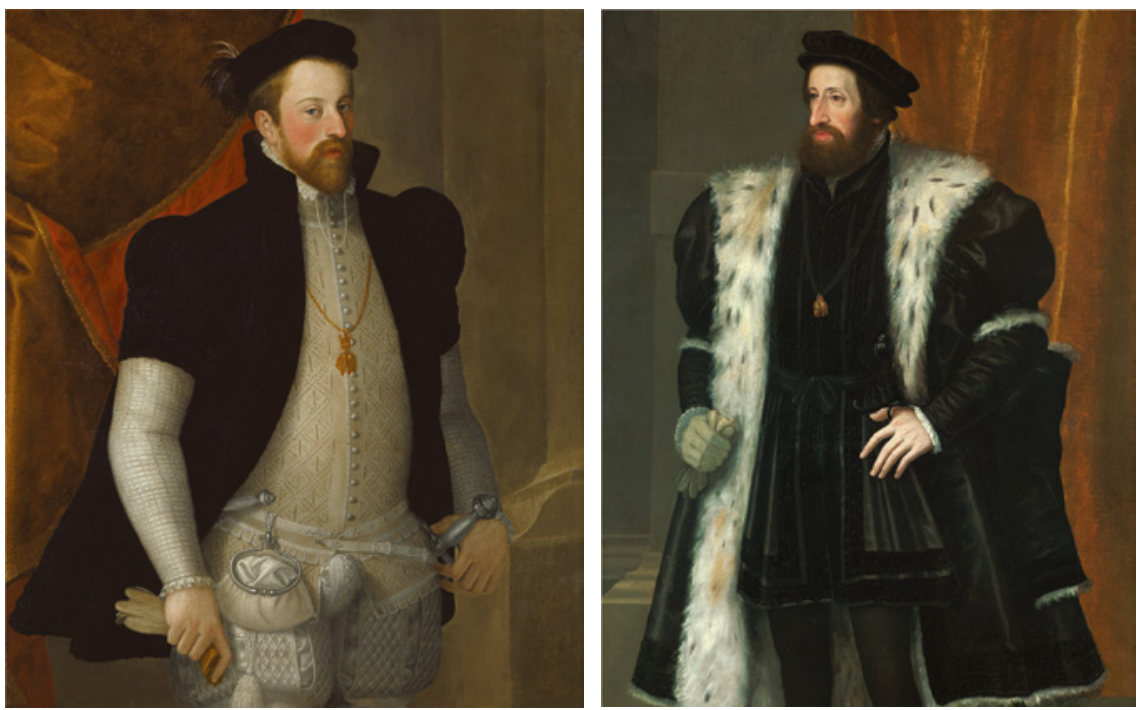

the Habsburg interest and their principal partisan in Augsburg, he maintained close contacts with the Imperial Court and was personally acquainted with Charles v. His acquaintance with Charles' brother, King Ferdinand, and with his children went back even further, to the time he spent as a young man at Ferdinand's court in Innsbruck. His services were rewarded with membership of the Imperial Council (1549) and of King Ferdinand's household (1551). So he was in a position both to inform Strada of the character, the interests and the requirements of the Habsburgs as prospective patrons, and to recommend him to them, if he chose. ${ }^{6}$ During their frequent visits to Augsburg the several members of the dynasty habitually lodged in the Fugger house, where Fugger acted as their host: and it is perfectly possible, even likely, that Fugger introduced Strada to his august guests in person.

The Imperial court would in any case have attracted Strada as offering opportunities of patronage even in the 1540 s, especially at events such as an Imperial Diet or a princely wedding, when the presence of a great number of princes and magnates would be assured. At such occasions the Imperial entourage would habitually be crowded with all sorts of hangers-on: not merely political agents of princes or free towns of the Empire and foreign dignitaries lobbying for the interests of their masters, but also clerics, humanists

6 It is not unlikely that Fugger did exert his patronage in this respect; probably in an informal way during a personal interview with Charles, Ferdinand or Maximilian, for instance when showing them round his collection. No written recommendation has been found, if it was ever sent. 
and artists in search of jobs, benefices or commissions. The most likely opportunity for Strada to have met the Marquis of Marignano would have been at such an occasion, for instance the Diet in Augsburg in 1547. So even if he had never been formally introduced to Ferdinand and his two eldest sons, he could have seen them and have been aware of some of their interests. Thus he would have known of Ferdinand's interest in antiquities and his taste for architecture in the antique manner-demonstrated in his refurbishing of the Vienna Hofburg and the beautiful Summer Palace he had built in the gardens of the castle at Prague for his consort, Queen Anna—and through Fugger he would have heard about the similar interest of the two young Archdukes. ${ }^{7}$

\subsubsection{Strada's Arrival at the Court of Ferdinand I}

So it is not surprising that Strada was eager to profit from the first opportunity to establish contact with Ferdinand and his court. This opportunity offered itself soon after his return to Nuremberg. As discussed in Chapter 2, in the autumn of 1556 Strada's one-time neighbour, the goldsmith Wenzel Jamnitzer, had been summoned to Vienna by King Maximilian, from whom he received a commission which kept him busy for some considerable time. At this time Archduke Ferdinand also entrusted him with a commission, the manufacture of an ambitious table-fountain depicting the Garden of Eden, for which he proposed that Strada, as a competent 'Maler' or painter, would prepare one or more Visierungen or designs. Strada thought it necessary, said Jamnitzer, to see the Archduke personally, both to be better informed about his wishes, and to show him various drawings and patterns, and he referred to Strada's own letter to the Archduke.

This document, of the same date as and enclosed in Jamnitzer's letter, reads as an undisguised bid for patronage. Strada stressed that, for an ambitious work as this, a simple drawing would not be sufficient: it needed a model [modello] or rather a three-dimensional matrix [patrone], such as one prepares when constructing a palace, for the use of the masters who are to be employed [in the project]. ${ }^{8}$ He dwelt on the need for detailed consideration of its iconography, and suggested that the execution should be closely supervised by one person who would well understand its conception. He continued that he

7 When Maximilian, as Viceroy of Spain for his father-in-law, made plans to regulate the course of the Pisuerga in Valladolid, he wrote to Fugger to recruit the hydraulic technicians he needed for this.

8 DOC. 1556-12-22, discussed above, Ch. 2.5.3: 'un modello, overo patrone, nel modo come si fa quando si vole edificar un palazzo, acciò che li maestri che lavorerano se ne possino servire<... >'. 
would be prepared to take on that task, on the condition that-subject to the Archduke's own wishes- - he would be solely in charge, that is, only:

in case Your Excellency is willing to charge me with [the supervision of] the whole project, and that I am to direct it [comandare], and that I have no other supervisor [sopra capo] than Your Excellency. ${ }^{9}$

This condition clearly indicates the confidence Strada had in his own capacities and the recognition of these by prospective patrons: in fact he trusted that the Archduke knew his name and had seen the numismatic works he had provided to Hans Jakob Fugger's library. In addition, he indicated that he possessed materials that could be of use in the conception and the design of the object:

I also possess many beautiful things that could be of use for the project, in particular a most beautiful book of animals in colour; also I could find you many [images of] rare fishes, which could be used for the rivers $<\ldots . . .^{10}$

This is a valuable hint as to the function of Strada's Musaeum, which was thus not merely a collection of objects of material value and of aesthetic or scientific interest, but which was intended to fulfil quite practical needs, and could, he thought, be of great use in the artistic and scientific enterprises both of himself and of his patrons.

Strada's evaluation of his prospects appears to have been quite correct, since the Archduke wrote by return of post to Jamnitzer to ask Strada to come to Prague to discuss the project, when he 'would graciously hear him, and thereupon condescend to open our minder further [to him]. ${ }^{11} \mathrm{He}$ also desired Strada take with him the books and other things that might be useful for the project. Jamnitzer answered the Archduke that Strada would arrive in Prague at Candlemas (2 February) as requested, and that he also would bring with him a quantity of 'geschmelzte dierlein', small animals cast in silver, that Jamnitzer had had made by one of his assistants. ${ }^{12}$

9 'Pero volendo Sua Excellenza darmi il carico di tutto, et ch'io abbia a comandare, et che non conoschi altro sopra capo che Sua Excellenza<... >'.

10 'Et anchora mi truova di molte belle cose che per essa servirebbe, e massime un libro de animali colorito belissimo; ancora li trovaria di molti pessi rari, che servirebbe per li fiumi<....'.

11 DOCS. 1557-01-07: 'auch ine gnediglich gern hören und darauf unser verrer gemuet mit gnaden eröffnen'.

12 DOCS. 1557-01-07 and 1557-01-27. The group consisted of an 'Orpheus sampt den thirlein und kreitlein', Orpheus with small animals and plants'; they were intended as a sample 
Strada set out from Nuremberg probably immediately after the 26 th of January, the date of Jamnitzer's reply. A lucky chance presented him with a second recommendation and a further work of art to present to the Archduke. Ferdinand had some time earlier requested Paul Pfinzing, a Nuremberg patrician serving as a secretary to Philip II, to obtain a good, full-length portrait of Charles v. Pfinzing had sought out the best portrait of Charles available in Brussels, which was a three-quarter length in the possession of Cardinal Granvelle. Granvelle had immediately ceded the portrait, painted by Titian, to Pfinzing, who had moreover procured the exact measurements of the Emperor, in order that the Archduke could have the portrait 'completed'. Unfortunately Pfinzing's luggage train had been attacked by robbers just before reaching Nuremberg, and though the painting was recovered, it had been damaged (and the Emperor's measurements had been lost). Having heard of Strada's visit to the Archduke, he asked him to take charge of the portrait, and to present it to Ferdinand together with his covering letter. In it Pfinzing gave his description of the incident and offered excuses, and recommended his messenger in laudatory terms: 'an exceptionally fine artist and a man also experienced in other fields', and he added that Strada, 'without my help—though that were quite justified—will extoll his art himself'.13

Strada's visit to the Archduke appears to have been short, and we have no indication of its outcome. Though the project regularly crops up in the sources during the next years, Strada is never mentioned: perhaps the Archduke did not share Strada's conception of the work, did not give in to Strada's demand of total control over its execution, or Strada himself meanwhile was too much occupied with other obligations. On the other hand it is perfectly possible that he did continue advising the Archduke and Jamnitzer — or both—in an informal way during the further development of the project, which never materialized for lack of silver. Already on 12 February Strada was back in Nuremberg.

of the sort to be included in the projected group of Adam and Eve in Paradise: should the Archduke not like them, he could return them, 'so mach's ich auf einen deckel zu einem drinkgeschir' ('then I use them to decorate the cover of a drinking cup').

13 DOC. 1557-01-26: 'ain treffentlicher feiner künstler und sonst erfarner mensch', and he added that Strada, 'one das ich es thue, wiewol es billich geschehe, sein kunst selbst loben wuerde'. It probably recommends rather than derogates the artistic proficiency of the Flemish painters of the day that none of them dared to tamper with a Titian original. The painting cannot now be identified with certainty: cf. Wethey 1969-1972, 2, p. 194, cat. nr. L-5. The style of the letter is instructive: compare the cringing tone and surfeit of ceremonial phrases of Pfinzing - a member of the Nuremberg patriciate - with the free, downto-earth practicality of Jamnitzer's and the urbane and self-assured manner of Strada's epistle: it is clear a social inferiority complex not necessarily made part of the mental make-up of a sixteenth-century artist. 
Strada did take advantage of his trip to Prague to pay a visit to Regensburg, where a Diet was in progress in the presence of the new Emperor. He was received in audience probably on 5 February, when Ferdinand accorded him an Ehrengeschenk of hundred Thaler. ${ }^{14}$ Poor Ferdinand! While engaged in complex and important political negotiations, and worrying about the Turks in Hungary and about the wayward behaviour of his eldest son, he was also beset by swarms of figures such as Strada seeking his patronage: only a few days later the Hofkammer made a list of recent payments to a number of similar clients. One can only hope that the talents of at least some of them occasionally distracted the Emperor from his cares, as will have been the case with Orlando di Lasso, who precedes Strada in this list. ${ }^{15}$ In view of Ferdinand's interest in Antiquity, and in particular in ancient coins, Strada's visit may likewise have served as a welcome distraction: Strada had prepared a present for the Emperor, a set of drawings of Roman Republican coinage.

This manuscript, the first volume of De consularibus numismata, is similar in concept and execution to the numismatic works he had produced for Fugger and for his unknown French patron. ${ }^{16}$ Its beautifully illuminated title page, including the Imperial coat of arms [Fig. 4.4], betrays its original destination: the panel in the pedestal of the left column is covered by a strip of marbled paper hiding a drawing of Charles v's emblem showing the Pillars of Hercules, accompanied with the famous device Plus Ultra. Ferdinand's appreciation of this gift was expressed in the Ehrengeschenk that he accorded Strada on this occasion, and in his interest in the second volume of the work, which Strada promised to finish for him. ${ }^{17}$

Strada presented his manuscript to Ferdinand not merely in the hope of obtaining the habitual financial reward, but also as a means to draw the Emperor's attention to his person and his qualifications. This is borne out by his

\footnotetext{
14 DOC. $1557-02-05$.

15 DOCS. 1557-02-05 and 1557-02-08.

16 ÖNB-HS, cod. 9411-9412; the Fugger manuscripts are now in Gotha and London, the French volume, dated 1554, in the Bibliothèque de l'Arsenal in Paris; cf. above, Ch. 3.3.

17 DOC. 1558-02-12: Strada refers to his visit in Regensburg. Von Busch 1973, p. 199 and p. 335, note 47 , cites this letter as directed to Maximilian. This is incorrect: it is addressed to the King of the Romans, which was Ferdinand I, whose succession to Charles as Emperor was formally confirmed by the College of Electors only on 14 March 1558. For the same reason Strada's dedication of his edition of Panvinio's Epitome pontificum romanorum of 1557 reads: 'Domino D. Ferdinando Romani Imperii Caesari designato'. Maximilian was elected King of the Romans only during the Frankfurt Diet of 1562 (election 24 November, coronation 30 November). The letter refers to Strada's meeting with the addressee in Regensburg, and the latter's visit to Strada's studio, probably in Nuremberg: since Maximilian did not set foot in Germany proper between his return from Brussels in the early autumn of 1556 (he merely spent one night, 11-12 September, in Regensburg) and the Frankfurt Diet (arrival 23 October) it is out of the question that Maximilian is meant.
} 


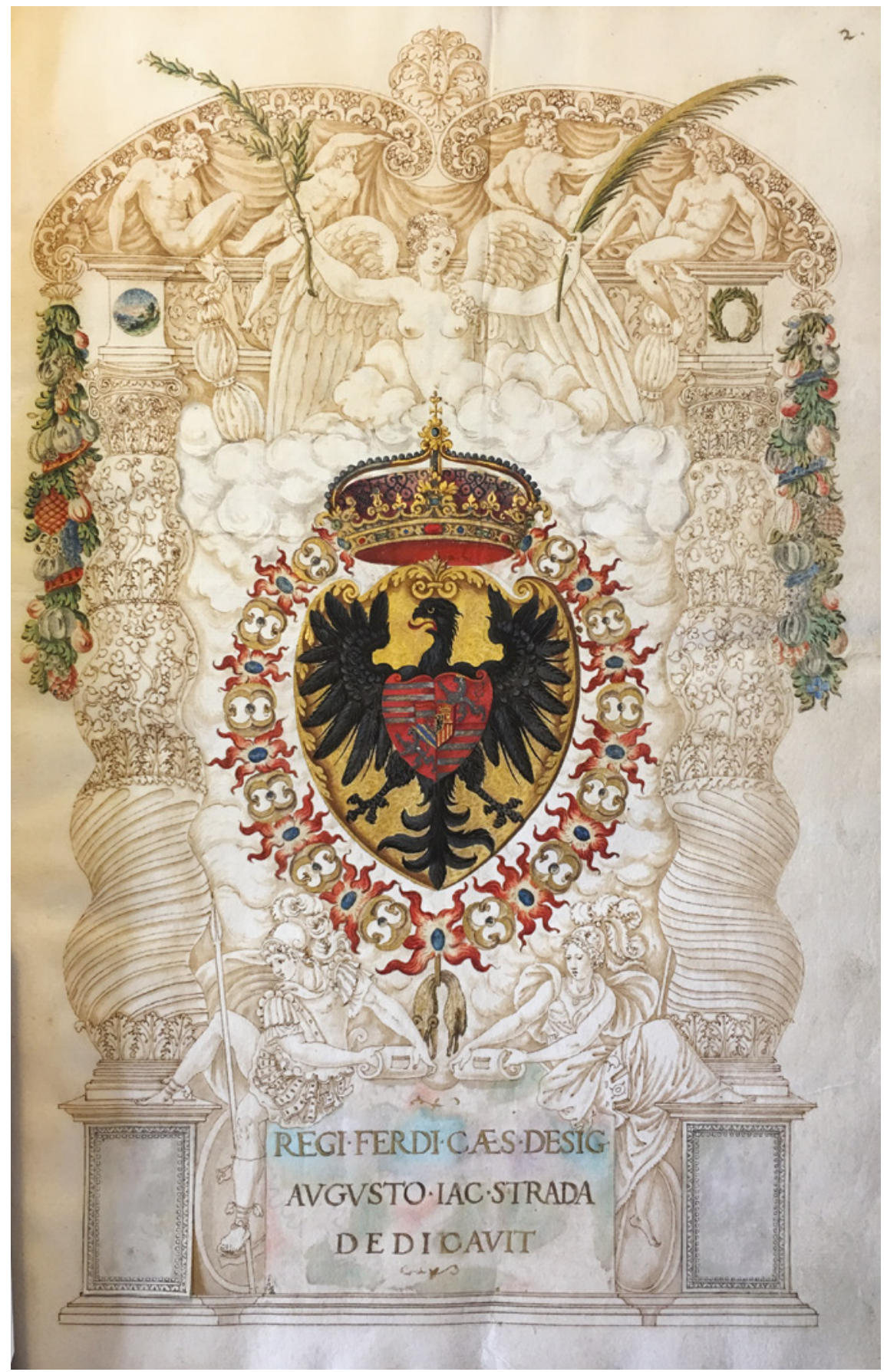

FIGURE 4.4 Jacopo Strada, frontispiece of his De consularibus numismata, a collection of drawings of ancient Roman coins. It was originally destined for Charles v, witness the emblem Plus ultra on the left pedestal, over which Strada pasted a strip of marbled paper before presenting it to Emperor Ferdinand I in 155; Vienna, Österreichische Nationalbibliothek. 
decision to dedicate his edition of the two books he had acquired from Onofrio Panvinio respectively to Ferdinand and to his elder son, King Maximilian. In order to supervise the printing of these books, the Fasti et triumphi and the Epitome pontificum romanorum, he must have gone to Venice in the spring of 1557, and it was probably there that he wrote and dated 'Idib. Maijs' his own dedicatory prefaces to both books.

Strada had gone to considerable trouble and expense to do Panvinio proud: he had opted for an expensive folio format, selected beautiful type, as Agustín recognized, had gone to the trouble of printing the chronological tables in the Fasti in black and red ink, and had illustrated them with imperial effigies printed from the blocks used for his own Epitome thesauri antiquitatum. Strada's ambition as a publisher is again apparent from the fact that he had them printed at his own expense and under his own imprint, furnishing the title page with a variant plate of the printer's mark he had used for his Lyon Epitome thesauriantiquitatum.

Strada dedicated his edition of Panvinio's Epitome pontificum romanorum to Ferdinand [Fig. 4.5]. This was a relatively simple chronology of the Popes, briefly giving a formal biography of a few lines, the dates and composition of the conclave in which they were elected, a mention of their death and the place of their tomb. But its principal component were the lists of cardinals created or deceased during each pontificate, each entry in these accompanied by an illustration of the relevant coat of arms. This, together with the extensive indices appended to the book, makes clear that it was merely intended as a convenient work of reference.
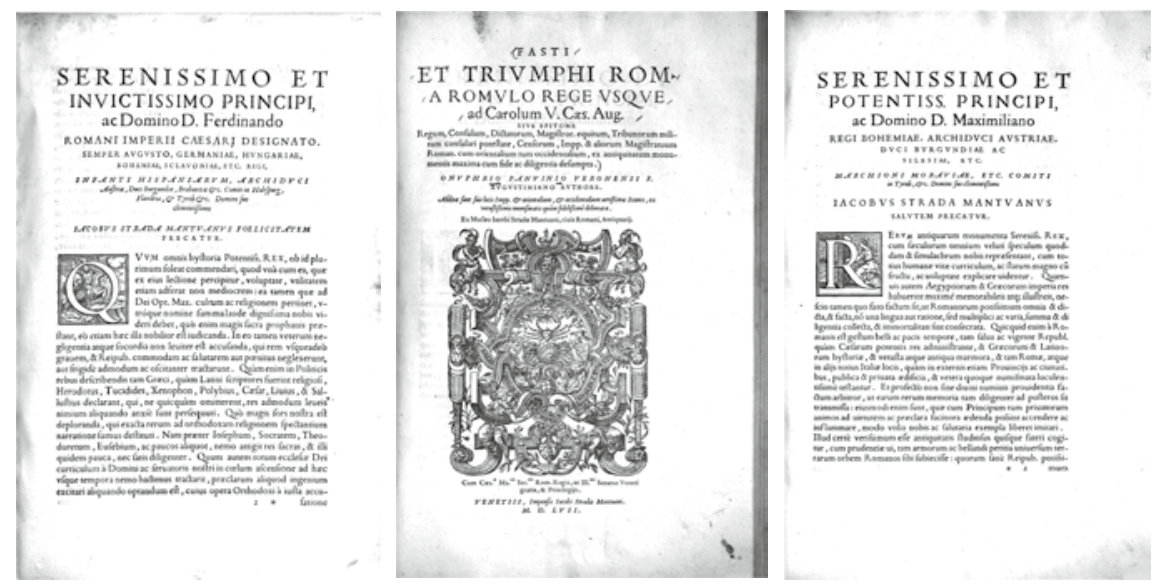

FIgURES 4.5-4.7 Strada's editions of Onofrio Panvinio's Epitome Pontificum and Fasti et Triumphi, which he dedicated to Emperor Ferdinand I and to King Maximilian II respectively. 
The Fasti et triumphi on the other hand, presenting a scholarly edition of the most important Roman inscription in existence, the Fasti Capitolini, was a book of far wider potential appeal and far greater utility [Figs. 4.6-4.7]. It was moreover a much more bulky volume, and more sumptuously printed. That Strada chose to dedicate this volume to Maximilian, rather than to the Emperor himself, can perhaps be explained by Maximilian's by this date generally known disaffection of Roman Catholicism: it would have lacked tact to present him with a book on the history of the Popes. Yet the dedication indicates that, after having established contacts with his father and his younger brother, Strada also wished to excite the interest of the young King of Bohemia and prospective Emperor. It seems to me that this was both because he had sanguine hopes of employment from this unusually erudite prince, and because he may have felt a deeper personal attraction for his aspirations and his character. Little as one can know about the personal sympathies of either, partly for lack of relevant sources, partly because of the veil under which a Renaissance prince had to hide his personal preferences, it seems that there was a sincere mutual esteem between them. This is suggested by Maximilian's later acts of patronage and the personal interest he would show in Strada's projects, as well as by the despair Strada expressed when referring to Maximilian's death, which had shattered his fondest hopes of lucrative patronage.

Strada would not meet Maximilian in person until a year later, after he settled in Vienna in April 1558. We have no indication of the king's response to the book that was dedicated to him. But it is clear that his father had been impressed by Strada's capacities. Though we do not know what contacts, if any, Strada maintained with the Emperor during the rest of the year, from a request Strada presented to Ferdinand, dated Nuremberg 12 February 1558, we know that he had not been forgotten. The Emperor was staying in Nuremberg on his way to the forthcoming Kurfürstentag at Frankfurt, during which the Electors were to confirm Ferdinand as Charles' successor as Emperor. Notwithstanding his doubtless pressing political engagements, Ferdinand took the trouble to visit Strada's house and to see his collection or Musaeum. Oddly enough Strada appears not to have been present in person, since he did not know what objects exactly the Emperor had inspected. ${ }^{18}$

18 DOC. 1558-02-12. The letter is not quite clear. It cannot be excluded that the visit Strada refers to had taken place on an earlier occasion: in that case probably during Strada's absence when overseeing the printing of Panvinio's books in the late spring of 1557 , for instance when Ferdinand travelled to Prague after the Diet at Regensburg, which closed on 17 March. But it is clear that Strada had been received in audience shortly before writing his letter, and he hoped to receive a reply before Ferdinand's departure planned for the day after. 
On this visit Ferdinand was accompanied by one of his most trusted advisers, Otto Truchsess von Waldburg, Cardinal and Prince-Bishop of Augsburg [Fig. 1.19]. This scion of an illustrious German military dynasty, the epitome of the German knight, was very conscious of the high duties imposed by the sacred office for which his rank and education had destined him. A feared adversary of the Protestants, he introduced many religious reforms in his diocese. He had had an outstanding education-like Hans Jakob Fugger he had sat at Alciati's feet at Bologna-which expressed itself in his intellectual concerns: he founded a university and a printing-press at his residence at Dillingen, both of which he made available to the Jesuits, and he used his frequent sojourns in Rome to build up an important collection of antiquities and contemporary works of art. His library at Dillingen was explicitly commended by Antonio Agustín, who visited it on his short trip as Papal nuncio to the Emperor in the spring of $1558 .{ }^{19}$ So his commendation of Strada's collection would be quite valuable.

\subsection{The Controversy with Wolfgang Lazius}

\subsubsection{The Catalogue of the Imperial Coin Collection}

Ferdinand's visit had impressed him sufficiently to summon Strada in person. During the audience he gave him two gatherings of the text and some proofsheets of the engravings of an illustrated catalogue of his own coin-collection. ${ }^{20}$ This catalogue had been first planned as far back as $155^{\circ}$ and was intended to document all of the Emperor's circa seven thousand ancient coins. It was prepared by Leopold Heyperger, one of Ferdinand's chamberlains particularly charged with the care of the works of art, who had provided the inventory, and the engraver Hans Sebald Lautensack, who as 'Kaiserlicher Maj<estät> Antiquitetenabconterfetter'-i.e. 'draftsman of antiquities of his Majesty the Emperor'-provided the illustrations. The Imperial Historiographer, Dr Wolfgang Lazius, was responsible for the scholarly commentary and supervised the project. The final responsibility of the project probably rested with Ferdinand's Oberstkammerer, Martin de Guzmán. ${ }^{21}$

\footnotetext{
19 On Truchseß, see Overbeeke 1994. Agustín's report to Panvinio on the German libraries he had seen in Agustín 1980, p. 290-291.

20 This and the following based on the letter Strada presented in person to Ferdinand I during his visit to Nuremberg [DOCS. 1558-02-12; see appendix 3a] and his letters to Ferdinand [DOC. $155^{8-02-21<a>]}$ and to his Oberstkammerer Martín de Guzman [1558-02-21<b>, see appendix $3 \mathrm{a}]$.

Some of the relevant documentation summarized in Kenner 1902.
} 
Lazius was an important man: a professor of medicine at Vienna University, he was well known for his researches in the ancient history of the Austrian territories, and was particularly esteemed by its rulers, who appointed him Imperial Historiographer and a member of the Reichshofrat or Aulic Council of the Empire. But it appears that his practical experience of classical numismatics was rather limited, and Strada immediately detected several serious mistakes in the sample he was shown. ${ }^{22}$ Ferdinand had asked him to take text and proofs home with him, and 'after having carefully read these two gatherings, and having seen the images of the medals', he strongly advised the Emperor not to proceed in the matter before having heard his opinion, when 'I will show you with arguments that otherwise the money is wasted, and not without censure of anyone who will see it'. Though Strada claimed that he did not like to speak ill of the work of others, he felt the Emperor's command obliged him to speak his mind, and he did not hesitate to offer Ferdinand to undertake the necessary corrections. In fact he probably considered the matter a heaven-sent opportunity to press his concrete services on the Emperor. He added that the second part of his manuscript on Republican coinage, promised when he presented Ferdinand with its first volume, would be ready within two months, 'and will be much better than the first one'. But he also offered to finish on his behalf another work which Ferdinand had seen in his studio (probably a similar work on imperial coinage, the Series Imperatorum), 'if I am accorded some fair financial compensation, so that I can maintain my small family'. In fact he wished for nothing better than to spend his time in Ferdinand's service, 'preparing for him my works, which would be the equal of those made in Rome, where I have learned this science [of numismatics]'. In a beautiful phrase he requested a decision of the Emperor: 'Hora se la Maestà Vostra li piace di acetarmi nel numero de li suoi virtuosi, del canto mio farò ogni debito per farmi honore': 'So if it would please Your Majesty to accept me among his learned men, I on my side will do everything I can to merit honour'. Claiming that he wished to leave Nuremberg anyway and return to Italy, Strada finally pressed Ferdinand for a reply before his departure, scheduled for the next day.

\subsubsection{Strada's Letter to Martin de Guzmán and his Move to Vienna}

Strada presented his request in person, but Ferdinand wisely did not commit himself as yet. But he did give Strada permission to correct the mistakes he had spotted in the sample of the catalogue. Two weeks later Strada sent the material back to the Emperor, by now in Frankfurt, and repeated his request. In it he refers Ferdinand to a more detailed account of his findings given in 
a long letter to Martin de Guzmán. ${ }^{23}$ From these letters it appears that Strada had sent back the material neatly sewn into a piece of vellum, so that no sheets would be lost, and that he had written his corrections of the errors it contained — of which there were many more than he had thought at first - in the margins. He criticised Lazius for not having read the lettering of the coins correctly, and therefore having misinterpreted a great many of them. Moreover the order Lazius had adopted bordered on the chaotic: he had mixed up coins of the Roman Kings with those of the Consuls, and those of the Consuls with those of the Emperors. In fact he strongly doubted that either Lazius or his engraver understood the material at all:

I am certain that Doctor Lazius cannot read them; and neither can the artist who works the copperplates. Because if they would understand them, they would not range the medals of the Kings of Rome among those of the Consuls, nor those of the Consuls with those of the Emperors; and neither would they exchange those of the Emperors, putting those that belong to one Emperor under another. And they would not commit so many errors, such as using the same medal several times, in different places. In future they are certain to commit [even] greater [errors], because the matter becomes more difficult the more one advances [in time]. So that I leave it to Your Lordship to judge what a beautiful thing they will produce; and if it ever sees the light, it may well be that every man of judgment will make jokes about it—not considering the expense they will have caused His Majesty.

Strada offered to undertake the necessary correction, provided that he would be given the credit: 'I would not want to be tutor to Doctor Lazius, for him to gain laurels with my corrections'. He then outlined to Guzmán, who had asked him to write 'l'historia de una hovero dua medaglie', the interpretation of one or two medals, how such a work ought to be put together. It should not be conceived as an object-catalogue, extensively describing and interpreting each individual coin, which would obviously entail constant repeating of matter, but 'per ordine come seguita la historia', that is as a chronological series of towns, Kings, Consuls and Emperors who had issued coinage, under whom the individual coin should be classed and described. Strada mentioned his own Epitome thesauri antiquitatum as an example, and it must be conceded that this system - which Strada had not invented himself-soon became the norm and is still adhered to in numismatic corpora of our own time. He also paid particular attention to the illustrations: he could easily teach the engraver how

23 DOCS. $155^{8-02-21<a>}$ and $155^{8-02-21<b}>$, the latter given in appendix $3^{\mathrm{a}}$. 
to correct the plates that had already been made, and stressed that the engraving should be carefully supervised:

$<\ldots>$ and it is also necessary that the master who engraves the plates should have a supervisor, and that he makes them better, and with more design ['et con piu disegno'], because he draws them so badly that they could not be worse, and he all does them in the same manner, and they make His Majesty believe that they look like that. Even though a medal is somewhat damaged, it does not for that reason lose the perfection of its design. They do not look at anything except the outside contours, showing these with the damages; so that who sees them would think that His Majesty has the ugliest medals in the world.

In his letter to the Emperor Strada makes no mention of his ambitions, but he did ask Guzmán to remind Ferdinand of his earlier request. He hoped that a decision would be taken before Ferdinand left Frankfurt, in order that 'I would not loose another opportunity about which I have been approached, and that in the end, because of the long delay, I would have neither the one, nor the other'.

Had Strada been more aware of the high esteem Lazius enjoyed in Vienna and at court, he perhaps would have worded his criticism more tactfully. Fortunately for him his old acquaintance Antonio Agustín had just arrived in Frankfurt as Papal nuncio. Strada, who himself had come to Frankfurt probably in connection with the book fair, but doubtless also to further his interests at court, told him of the projected catalogue. As perhaps the foremost numismatic expert of his day, Agustín was asked to give his opinion. As he told Panvinio, 'io ho trovato che c'è puoco di buono, et cosi manderemo a monte la stampa<...>, 'I found that there was little good in it, and so we will end up frustrating the printing. But he was surprised, because-like Panvinio-he was aware of Lazius' other books, and had great respect for him: 'Volfango è molto antiquario et buona persona et dotta.'24

Agustín's commendation of Strada's criticism obviously persuaded Ferdinand of his bona fides, because now he did concede Strada's request to be employed, and Strada immediately asked the Nuremberg Council to be permitted to live for three years in Vienna without losing his rights as a citizen of the town. ${ }^{25} \mathrm{He}$ had anticipated this permission, because he had already transferred his household to Vienna when Agustín himself arrived, doubtless accompanying the Emperor, who made his official entry on the 15th of April:

24 DOCS. 1558-04-11 and 1558-05-02.

25 DOC. 1558-04-30. 
I should not omit telling you that in Vienna I found Strada already there, having a row with Volfango Lazio about that book of the medals of the Emperor, and he had brought his wife and household with him. ${ }^{26}$

\subsubsection{Wolfgang Lazius}

It is not surprising that Strada was at loggerheads with Wolfgang Lazius. Lazius (1514-1565) [Fig. 4.8 and 4.10] was a respected doctor who belonged to a prominent Vienna family: his mother was a sister of the Vienna Bürgermeister and Imperial Bausuperintendent Hermes Schallautzer. Already at the age of twenty-two he had been lecturing at Vienna University, where he was appointed professor of medicine in 1541. But his principal interest was regional history: his first publication in this field was a history of his native city, published by Oporinus in $1546 .{ }^{27}$ In 1547 Ferdinand appointed him Imperial Historiographer, and provided the means to conduct research into the history of the Domus Austriae and its territories, and to collect written sources for this. Lazius had already been hunting for manuscripts before this commission; now he undertook extensive travels to obtain materials, first in Austria proper, later also in Switzerland, Bavaria and in Vorderösterreich, the Habsburg possessions in south-western Germany and Alsace. He published a catalogue of his finds, which included seventy-one unknown manuscript sources, forty-three of which would find their way into the second volume of Conrad Gesner's Bibliotheca Universalis. He drew upon these sources for his own research, which resulted in no less than twenty-five publications printed between 1546 and $1564 .{ }^{28}$ These included editions of some of the texts he had found and an important book on the migration of the Germanic peoples in the late Roman Empire, as well as several maps of the Austrian territories. Lazius' intellectual standing was recognized by his colleagues, who elected him repeatedly as Dean and as Rector of Vienna University, and his political acumen was sufficiently esteemed by his Imperial patron to earn him membership of the Reichshofrat, the Imperial Aulic Council. His high standing was reflected in the house belonging to his family, the Lazenhof, which is still standing more or less as he rebuilt it, and which housed his library and collection [Fig. 4.9].

It is perfectly understandable that such a prominent scholar did not take kindly to criticism from someone like Strada, criticism the more painful

\footnotetext{
26 DOC. 1558-06-11.

27 Vienna Austriae: Rerum Viennensium Commentarii in quatuor libros distincti, Basel (Oporinus) 1546. On Lazius, see Horawitz 1883; Mayr 1894; on his controversy with Strada, see Von Busch 1973, pp. 199-201; Louthan 1997, pp. 27-42. 

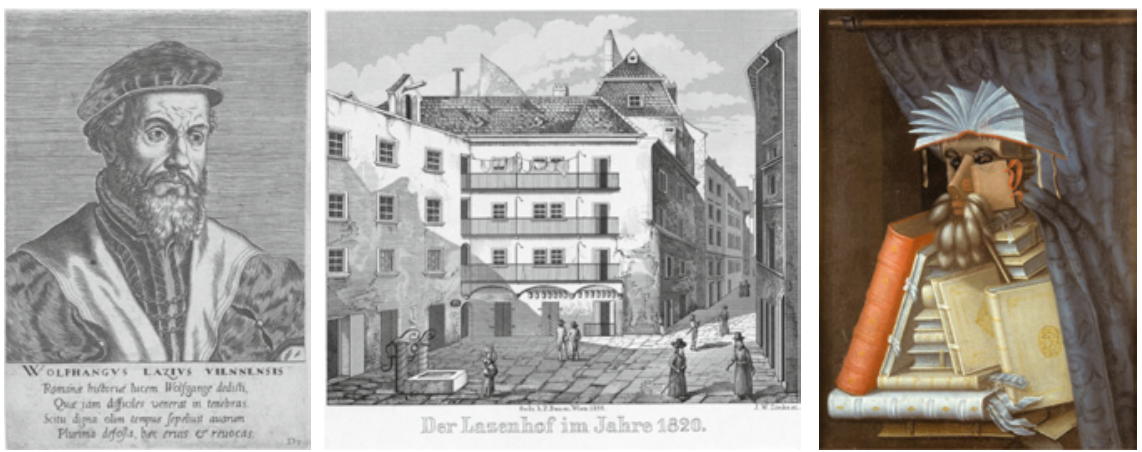

FIGURE 4.8 Philips Galle, Portrait of Wolfgang Lazius, 1555, woodcut.

FIGURE 4.9 Johann Wilhelm Zinke, The Lazenhof, Lazius' house in Vienna, as it was in 1820, print of 1856 .

FIGURE 4.10 Giuseppe Arcimboldo, The Librarian, traditionally identified as Wolfgang Lazius, Skokloster Castle, Sweden.
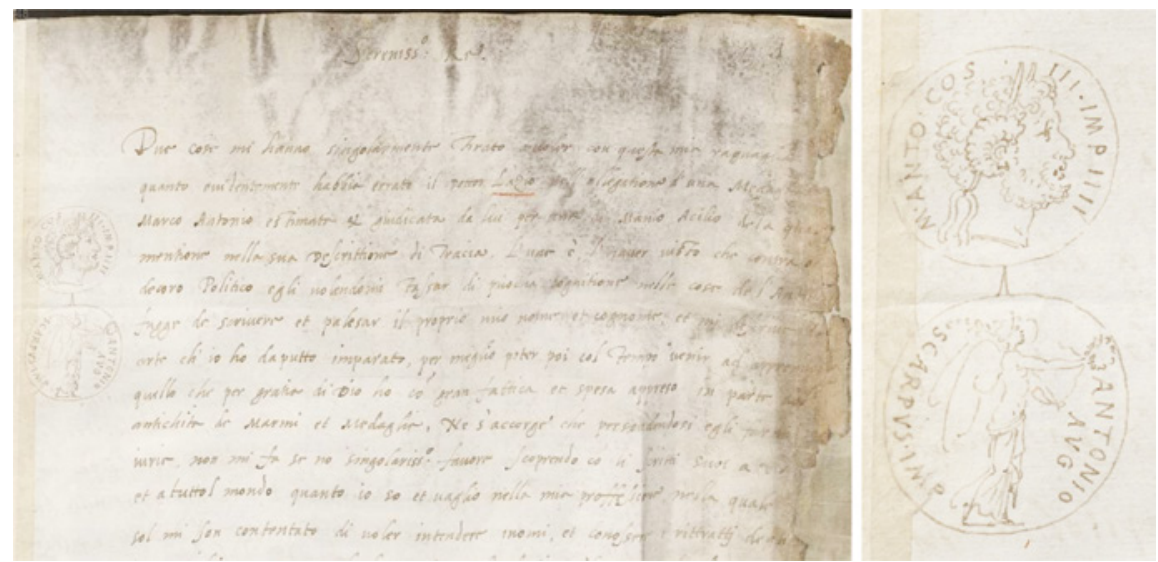

FIGURE 4.11 Jacopo Strada, obverse and reverse of a coin of Mark Antony, sketched in the margin of his letter to King Maximilian II, Doc. 1559-06-0o MUNICH, BAYERISCHE STAATSBIBLIOTHEK.

because it was basically justified. Lazius had specialized in later Roman and medieval literary sources, including the Nibelungenlied — such interest in itself earns him an honourable place in the history of scholarship-but he appears to have been much less aware of the modern antiquarian method derived from Budé and Alciati and their pupils, a method perfected in the Roman milieu of which Agustín was part. In contrast, Strada had first-hand acquaintance of this method, and could with some justice claim that his works 'potriano star al paragone di quelle di Roma, dove tal scienza ho imparato' - 'could bear 
comparison with those of Rome, where I have learned this science'. In his letter to Martin de Guzmán Strada had attacked Lazius without even the least respect for his very real merit, and though Guzmán hopefully had been tactful enough not actually to show Lazius this letter, he must at least have acquainted him with the gist of it.

\subsubsection{A Possible Solution: Onofrio Panvinio?}

As Oberstkammerer, Guzmán was ultimately responsible for the project, as he was responsible for the internal peace of the Imperial household. He cannot have been very happy with the controversy. Though convinced by Strada and Agustín that Lazius was not sufficiently competent to finish the catalogue without more specialized assistance, neither he nor the Emperor would have wished to offend such a prominent scholar and well-deserving servant by replacing him by his tactless rival.

It was Agustín who suggested a solution: he proposed that his good friend Panvinio would be asked to come to Vienna, to work in a team including both Strada and Lazius himself. He hoped his own presence would mitigate the effects of the existing mutual antagonism between Strada and Panvinio on the one hand, and Strada and Lazius on the other. But soon it transpired that Agustín, who had returned to Rome accompanying Guzmán, sent as envoy to officially acquaint the Pope with Ferdinand's election, would not return to Vienna.And he doubted the Emperor's patronage:'La sua natura [= Ferdinand's], né di questo Signor Imbasciator [= Guzmán] non è di spender molto in queste cose'. Yet he hoped Panvinio would travel to Vienna, and applauded the latter's suggestion to take Enea Vico with him: together they could replace Strada:

$<\ldots>$ then [the two of you] you could send Strada into the woods, and you will succeed with the help of Lazius, who delights in commissioning engravings. All together you would make a beautiful book for the Emperor. ${ }^{29}$

\subsubsection{Lazius' Counter-attack and Strada's Defence: The Letter to King Maximilian}

Meanwhile Lazius had launched a counter-attack. In April he printed a sample of his catalogue, provided with a dedication to Guzmán, in which he refers in general terms to invidious detractors of his work. Renate von Busch found a copy of the same work which includes a dedication to Urban von Trenbach,

29 DOCS. 1558-o6-11 and 1558-06-25. Agustín particularly wished Panvinio to go because this would give him the opportunity to visit the German libraries, where he would find so much material for his principal subject of study, the history of the Church. 
Bishop of Passau, in which Lazius passed Strada's criticism off as the envious ignorance of a mere painter, and an Italian at that. ${ }^{30}$ Over a year later Strada responded indignantly to a similar allegation, probably not the one mentioned here, but one contained in an unidentified (lost?) pamphlet Lazius appears to have devoted to the question, and which, though already printed, had not been actually published. ${ }^{31}$ In this attack Lazius appears to have referred to Strada as a mere goldsmith, without even mentioning his name and function as Imperial Antiquary, and to have attributed to him the erroneous opinion that ancient coins depicting Romulus and Numa were actually struck under the rule of these archaic princes. Strada was furious about this attack, which he did not expect, because Lazius appears to have concealed his understandable resentment: 'which most annoys me is that Lazius has deceived me, because always when he met me, he greeted me from afar, and then he thumped me on my shoulders $<\ldots .$. . $^{32}$

In an extensive apology handed personally to King Maximilian, rather than to the Emperor himself, Strada began by demolishing the interpretation of a coin of Mark Antony given in Lazius' description of Thrace, in his Commentariorum rerum Graecarum of $155^{8-1559}$ [Fig. 4.11]. ${ }^{33}$ Strada sent a copy of this apology and a covering letter to Hans Jakob Fugger, and together these provide a lot of information about Strada's position in Vienna at that time. It appears that Strada was particularly nettled by Lazius' dismissing his qualities as a scholar and a gentleman: the passage serves as an illustration of the discussion on the social position of the artist so common in the Renaissance. Lazius' reference to him as a mere goldsmith most have been the more galling because-notwithstanding his doctorate and his intellectual and political prominence-Lazius was a commoner, while Strada himself was after all a nobleman. Perhaps Lazius had not been very wise in his attack: in any case Strada neatly turns the argument against him, by stating that he had studied 'larte ch'io ho da putto imparato', i.e. the craft of the goldsmith, with the explicit purpose:

$30 \quad$ Commentariorum vetustorum numismatum specimen, Vienna (Michael Zimmermann) 1558; the copy in Stuttgart, Landesbibliothek, Allg. G. fol K 176 , includes the variant dedication to Trenbach; cf. Von Busch 1973, pp. 200-201 and 337-338, notes 55-57.

31 DOC. 1559-06-oo. Strada presented his protest to the King shortly before June 6th, when Strada sent Fugger a copy; in the accompanying letter (DOC. 1559-06-06) he referred to 'quel folio contro di me' by Lazius: in the context obviously a sheet, i.e. a pamphlet, rather than a folio-size book.

32 DOC. 1559-06-06; see appendix за.

33 Von Busch 1973, p.338, note 61 erroneously implies that the attack on Strada was included in this work itself; Strada's letter to Fugger (DOC. 1559-06-09) makes clear that it was a separate pamphlet. Strada's comment discussed in JANSEN 1993, pp. 213-214. 
$<\ldots>$ better to learn in time what I have, with the grace of God and with great effort and expense, been able to master in the field of marble antiquitiesand medals; and neitherdoeshe [= Lazius] realize that, thinking to do me an injury, in fact he does me an outstanding favour, demonstrating in his writings to Your Majesty and to all the world, how much I know and am capable of in my profession; in which I have not only contented myself with identifying the names and recognizing the portraits of the people of Antiquity, but also have succeeded with my efforts over time, to be able not only to draw them on paper, but also to model them both in gold and [other] metals, and to carve them in marble.

Moreover Strada slyly suggests that, if Lazius really considered as demeaning the craft and the expertise of the goldsmith, it was hardly consistent with either the duty he owed his Imperial patrons or with common civility, to indicate Strada, 'known to the world as a servant of both His Imperial and of Your Majesties as Jacomo Strada Antiquario', with that term, for 'everyone knows that the honour and shame of the servant reflect in equal measure upon the honour and shame of his master'.

Strada's letter to Maximilian was an effective act of revenge, since he could tell Fugger that:

His Majesty the King was quite annoyed that the said Lazio had accused me in this manner, and I believe that it has gained him little credit with His Majesty; and neither with many other learned men, not having been able to defend himself, or even having known how to; because against reason [mere] excuses have no value.

Maximilian had in fact commissioned one of his courtiers, one 'Signor Piller', to mediate between the contestants, and Lazius had retracted by stating that he had intended no offence, and that he was willing to have his pamphlet reprinted (doubtless meaning without the offending passage). But Strada told Fugger that he was not ready to forgive Lazius, 'o per tardo o per tempo', and that he rather hoped that the latter would publish the original version, so that he would have an excuse to respond publicly. 'Mon Signor d' Agria'-a new friend, the learned Croatian-Hungarian diplomat prelate Antun Vrančić (Antonius Verantius, Antal Verancsics; 1504-1573), at the time Bishop of Eger/ Erlau and Imperial Legate to the Council of Trent-had advised Strada not to apply to the King, but to respond publicly by printing an apology 'or rather an invective, and have it printed just as he had printed that broadsheet against 
me. ${ }^{34}$ Strada had finally decided against this because Lazius had not published his pamphlet (though doubtless he had circulated it among his friends at court), and Strada was afraid that he would offend too many people by an open reply.

\subsubsection{Outcome of the Affair}

This letter is the last we hear of the controversy. The planned catalogue was never realized: though Lazius' numismatic incompetence had been sufficiently demonstrated, the Emperor could hardly give the task to someone else. After his death in 1565 perhaps the need was less felt, because of the presence of Strada's numismatic manuscripts in the Hofbibliothek, which included most of the more important coins in the Imperial collection. ${ }^{35}$ The open quarrel between Lazius and Strada was probably hushed up in some way, though they never became friends. ${ }^{36}$ For Strada the positive aspect of the controversy was that it made his name known to everyone who counted immediately upon his arrival at court: on the principle that even bad publicity is better than no publicity, he could take any hostility he doubtless met with in his stride. He had moreover established his competence as an antiquary, and could claim to King Maximilian to be-as we have seen-'connossiuto per mondo provisionato da la Cesarea et [Vostra Maestà] per Jacomo Strada Antiquario'.

Though his explicit assumption of the style of Imperial Antiquary appears to have been tacitly condoned by King Maximilian, it was not officially recognized until some years later: the Emperor would have been careful not to offend Lazius' feelings more than necessary. Because he had been asked to come to court to enter Imperial service, already in November 1558 Strada had requested that he would be formally enrolled in the Hofstaat, the Imperial

34 That Strada did not boast in vain of Vrančićs interest is borne out by the long letter in Latin the Bishop addressed to him a few months later, apostrophising Strada as 'urbanissime Strada' and similar complimentary epithets (DOC. 1558-12-04); cf. below, Ch. 11.1.

35 It should be noted that Strada did not use the Imperial collection for his $\Delta \iota \alpha \sigma \chi \varepsilon v \varepsilon$, in which hardly any coins are described from the exemplars in Vienna: the drawings and descriptions in his numismatic works were based on the material he had collected in the years before he came to court.

36 Strada did obtain or compile a manuscript based on one of Lazius' published works, Commentariorvm Reipublicae Romanae illius, in exteris prouincijs, bello acquisitis, constitutae, libri duodecim, first printed by Oporinus, Basel 1551, which he intended to republish in an augmented second edition, since it is added to one of the copies of his Index sive catalogus [Appendix D, nr. 46]. 
household, and that a salary should be fixed. ${ }^{37}$ But the first record of payment we have dates only from a year later, when he received his annual salary of 200 Gulden. This was the remuneration that a month later, 31 January 1560 , was decided upon when Ferdinand finally granted him an official appointment: not, it should be noted, as Imperial Antiquary, but as 'ein Baumeister bey unsen Gebewen alhier': an architect for the Imperial buildings in Vienna. ${ }^{38}$ Only in 1563 , shortly before Ferdinand's death, Strada would be accorded a second Pension or Dienstgeld of 100 Gulden, in the capacity of 'Diener und Antiquarius', servant and antiquary. ${ }^{39}$ So Strada had finally realized his ambition to obtain the patronage of the principal secular ruler of Christianity. He would serve Ferdinand I and his successors in his double capacity until 1579, when he resigned his court-appointments; having settled in Vienna, he soon acquired a house of his own, and would remain there for the rest of his life.

\section{3 'Obwol Ir.Maj. den Strada selbst dier Zeit wol zu geprauchen”: Strada's Tasks at Court}

\subsubsection{Introduction}

Strada's decision to move to Vienna indicates that he highly appreciated the Imperial patronage which he had obtained, and which he managed to retain for twenty years. I have elsewhere discussed the advantages it brought him, by reviewing the instruments of patronage available to Ferdinand and Maximilian and listing their application in Strada's case. ${ }^{40}$ Though where men of letters and learning, artists, musicians, and so on were involved, the criteria governing their application may have deviated from the norm, these instruments were essentially the same as those employed to bind any potentially useful servant to the ruler, or to reward the achievements of any deserving subject. As in other cases, the patronage Strada enjoyed was partly composed of a string of small favours and privileges, the cumulative importance of which counterbalanced the periodical remuneration he received. Yet the salary or pension remained the most important single element of the reward, because it was the most formal expression of the relationship existing between patron and 'client'. As such

37 DOCS. 1558-10-00, 1558-11-0o and 1558-11-24; from the latter it transpires that Hans Lautensack had supported Strada's request, or had been asked for comment.

38 DOC. $1559-12-20$ and 1560-01-31.

39 DOC. $1563-00-00$.

40 Jansen $1988<\mathrm{c}>$; slightly revised English version: Jansen 1992. 
it had a symbolic significance that equalled or transcended its material value. In 1579 Strada's pension - in any case never more than a quite modest portion of his total income - had not been paid for five years, and after Maximilian's death the new Emperor had hardly made use of his services. But Strada still felt obliged to resign formally before offering his services to Rudolf's brother, the Archduke Ernest. ${ }^{41}$

Yet also during Maximilian's lifetime Strada enjoyed great liberty of action and was never required to limit the exercise of his talents to the Emperor's own commissions. On the contrary, he was encouraged to spend much time and energy on his own projects, and was able to work extensively for other patrons, such as Duke Albrecht $\mathrm{v}$ of Bavaria. It is doubtful whether this freedom from constraint may be interpreted as symptomatic for the process of emancipation of the artist as postulated in Martin Warnke's study of the court artist of the Ancien régime. ${ }^{42}$ Like so many other court-artists Strada was after all not only an artist, but also and at the same time a merchant, a man of letters, a nobleman and courtier. Strada's case suggests that a patronage relationship of this type was based on mutual and complementary interests, and consisted in an even exchange of diverse, but equivalent advantages. Strada drew his modest pension and enjoyed the prestige that his function as Imperial Antiquary procured him. Though this prestige is difficult to asses, Strada certainly valued it highly, so it must have been of use to him in the realization of his ambitious projects. It is reasonable to suppose that, in return, the Emperor expected to profit from Strada's erudition and artistic proficiency and from the added distinction that his presence - and that of the small but lively cultural meeting-place centred on his house and exquisite Musaeum-conferred on the principal residence of the Austrian branch of the Habsburg dynasty. ${ }^{43}$ The remainder of this book will attempt to give some substance to this assumption.

From the relatively detailed review of the material and immaterial advantages Strada obtained from his patrons, the Emperors Ferdinand I, Maximilian II and Rudolf II, we know exactly what salary he was paid, and when and even from what sources he obtained it. The combined sum of the two annuities he received shows that he ranked somewhere in the middle of the court hierarchy, a level which included both the lower ranking courtiers-noblemen holding court-appointments as gentleman of the Imperial Chamber or Stable 'with two or three horses' - as well as professionals, both noblemen and commoners, fulfilling specifically defined functions: doctors, chaplains and artists attending

41 DOC. 1579-05-00.

42 Warnke 1985.

43 The preceding paragraphs are adapted from Jansen 1992, pp. 201-202. 
the person of the Emperor, as well as the lawyers and accountants running the chancery and the Hofkammer or treasury. Taken together, the further acts of patronage that Strada obtained from Maximilian II - his assistance in acquiring and rebuilding his Vienna mansion, his insistent recommendations to other princes to aid Strada in his affairs and his ambitions for his family, and the formal recognition of his noble status-are exceptional: they demonstrate that Strada's services were highly valued. It is therefore odd that so very little is known about what these services actually entailed. In fact Strada's function at the Imperial court is the largest and most glaringly blank spot on the map of his career: whereas its size and shape can be roughly defined, its contents can only be conjectured. For any real understanding of Strada's career this conjecture must be hazarded. Based on the assumption that the patronage he received was indeed a recompense for services rendered, whatever their nature, the conjecture first relies on Strada's few concrete activities on the Emperor's behalf that are documented. To give substance to the rather hazy picture then emerging, Part II of this study will be dedicated to Strada's activity as an architect, while Part III concentrates on his role in the collecting activities of his patrons and on his own collection. In both cases comparisons with documented activities for other patrons, in particular for Duke Albrecht $\mathrm{V}$ of Bavaria, will be discussed and the analogy used to underpin his conjectured role in Vienna.

\subsubsection{Strada's Documented Activities on Behalf of His Imperial Patrons}

Considering that Strada remained in Imperial service for over twenty years, and in two different functions, his concrete activities in those capacities that are documented are quite few. As we have seen, his earliest activities on behalf of members of the House of Austria preceded his appointment at court: his involvement in Archduke Ferdinand's projected silver Garden of Eden and his advice on the planned catalogue of the Emperor's medals have been discussed above.

Soon after his arrival in Vienna, Strada was called upon to exercise a third of his accomplishments, his understanding of architecture. In October 1558 he was summoned, together with Hermes Schallautzer-as Bausuperintendent responsible for the management of the Imperial building projects in Viennaand the Imperial Architect Pietro Ferrabosco, to examine in the presence of Ferdinand himself, the model for the arcades of the Hofspital, a charitable institution that was being built next to the Vienna Hofburg at the Emperor's expense. The original model for the Hofspital had been presented to Ferdinand by his architect Sigismundo da Preda in 1549; but Ferdinand had decided to add superimposed arcades to the new building. It was the model for these 
arcades, prepared by yet another of the Imperial Baumeister, Benedikt Kölbl, which was discussed and approved by this ad hoc committee. ${ }^{44}$

In the first half of July 1559 Schallautzer again asked Strada and Ferrabosco to give advice, this time on the planned decoration of the ceiling of the great hall of the Hofburg at Innsbruck, a project which will be discussed in some detail below. On the 27th of April of the following year, Schallautzer asked him again to participate in a similar meeting: with Ferrabosco and the Italian sculptor Natale Veneziano Strada was to discuss the plans for the funeral monument of Emperor Maximilian I in the Hofkirche at Innsbruck, which was specially built to receive it. The committee was to prepare a Gutachten, an advice, on the shape of the tomb proper, which was to be placed at the centre of the group of over life-size bronze statues of Habsburg 'gesibt [und] freundschaft' - ancestors and allies - which had first been commissioned, fifty years earlier, by Maximilian himself. Its deliberations likewise will be discussed below. ${ }^{45}$

The tomb was the principal and most prestigious dynastic commission undertaken by Ferdinand I; so Strada's participation in the committee demonstrates considerable confidence in his artistic expertise. It is this confidence that, on 31 January of 1560, had motivated Ferdinand to formally appoint Strada as one of his architects, specifically for the projects under construction in Vienna:

Graciously considering the experience and competence we have observed our faithful and dear Jacob Strada to possess in the matter of building, we have graciously appointed him as an architect for our buildings here [= in Vienna $]^{46}$

Strada's activities as such are attested by the presence of his name in a document of 1562 listing the names of the architects involved in restructuring the Hofburg, but no information on his share in the work has been preserved. ${ }^{47}$

44 Grün 2014, p. 242, n. 1172; on the Hofspital, see below, Ch. 6.1.

45 Ch. 6.2.; the memorial referred to was communicated to Ferdinand by his architect, Hermes Schallautzer, doubtless also present at the meeting; it is printed in Schönherr 1890, p. $265^{-266 .}$

46 DOC. 156o-01-31 [HKA, Gedenkbuch Nr. 86, fol. 44 verso; Lietzmann 1987 p. 113, note 73].

47 DOC. 1560-01-31; but he had in fact already been awarded a first payment of his annual salary over 1559 (DOC. 1559-12-20), and in a note to the Emperor Benedikt Kölbl had referred to him and Ferrabosco as 'Ihrer Majestäts Baumeister' (HKA, NÖHA W 61/C59, fol 172 r, cited in Lietzmann 1987, p 113, n 71). The list of architects cited in Kühnel 1959 p. 320 (HKA, NÖHA, W 61/A2, fol 304 v; cited Lietzmann 1987, p. 113, n. 73). 
In August of 1560 Strada obtained a passport for a trip to Venice: this trip, however, was undertaken in his private interest, to recover some debts due to him. While in Venice he did buy some antique sculptures, but these appear not to have been destined for Ferdinand (more likely Strada bought them on behalf of Hans Jakob Fugger or even merely for his own collection). The nobleman Andrea Loredan, having heard of the high prices Strada had paid for these, offered Strada part of his own celebrated collection. Strada did indeed approach the Emperor, but this appears to have been his own initiative, and Ferdinand showed no interest. ${ }^{48}$

The next instance of a concrete service dates only from after Ferdinand's death, and is merely documented because it entailed some travel expenses: Strada was sent to Prague in connection with the tomb of Ferdinand and his consort that was to be erected in St. Vitus Cathedral in Prague. ${ }^{49}$ The tomb, which is no masterwork [below, Figs. 9.02-9.03], would ultimately also receive the remains of Maximilian II himself. It was executed in Innsbruck by Alexander Colin and his workshop between 1566 and 1589; again there are no concrete indications exactly what share Strada had in its conception.

In November 1566 Strada again was given an advance for his travel expenses, when Maximilian sent him to Munich at the pressing request of Duke Albrecht $\mathrm{v}$ of Bavaria. Maximilian wrote to his brother-in-law that he assented to Strada's departure 'wiewol ich sainer in etzlichen sachen nit wol geraten khan', 'though in many things [?projects] I cannot really miss', which indicates that, notwithstanding the dearth of concrete information, Strada was not inactive in Vienna itself. He would be lent in this manner to the Duke on two further occasions, in 1568 and in 1570 . His activities for that patron will be discussed below. ${ }^{50}$

On the second of these occasions, in November 1568, when Albrecht suggested that Maximilian, because of his absence from Vienna, would for some while have no need of Strada, the Emperor again had noted that in fact he did have good uses for his erudite servant. It is very likely that the Emperor at the time was consulting Strada regularly in connection with the design of the large garden and its ample pleasure pavilion, the Neugebäude, which he was planning near his hunting lodge at Kaiserebersdorf, some miles east of Vienna. A letter from Hans Jakob Fugger to Strada of the 13th of the same month implies

48 DOC. 1560-08-20; Von Busch 1973, p. 202 and note 69. Strada would acquire the Loredan collection a decade later on behalf of Duke Albrecht v of Bavaria (cf. below, Ch. 12.3).

49 DOC. $1565^{-0}-28$.

50 DOC 1566-11-18; shortly before his departure the Emperor granted Strada a travel allowance (DOC 1566-12-18). Strada's trips on behalf of Duke Albrecht discussed below, Ch. 12.3. 
that the latter had in fact provided a design that had been well received by his patron. ${ }^{51}$

In April 1569 Strada was sent to Pressburg (Bratislava), since the fall of Buda to the Turks the effective capital of Hungary. The chapel of the castle, which served as the principal royal residence, had been decorated with an elaborate programme of religious scenes designed and painted by Giulio Licinio. These paintings have not survived, but they were framed in stucco and surrounded by grotesques by Cesare Baldigara and Ulisse Romano, which have recently been rediscovered and restored [Figs. 9.4-9.5]. Begun in 1563, the project was nearing completion; Strada's task was to inspect it and to give an estimate of the remuneration Licinio was entitled to for this prestigious work, unfortunately destroyed or removed in the early nineteenth century. ${ }^{52}$

In 1572 or 1573 Strada provided the Emperor with twelve antique portrait heads and a bust, the former at 40 Kronen each, the latter at 6o Kronen. It is not known whether these were statues from his own collection-perhaps those bought at such high prices during his visit to Venice in 1560 ? - or whether he had negotiated their acquisition on the Emperor's explicit commission during his last stay in Venice in 1570. It is likewise unknown what was done with them, but it appears likely that they were intended for the decoration of the Neugebäude: at least since 1566 Maximilian had been actively engaged through his envoys and agents in Rome to obtain 'varias antiquitates, que haberi possunt, artificiosissimas et elegantissimas ad ornatum hortorum spectantes', that is, antique sculpture suitable to decorate the garden he was planning. The total sum Strada received-he was paid 810 Gulden, the equivalent of 540 Kronen - was almost thrice his combined annual salary, and therefore not inconsiderable. ${ }^{53}$

The numismatic manuscripts Strada had dedicated to Ferdinand I and Maximilian II in the 1550 s had not been solicited, but had been presented as gifts, to draw the attention of these potential employers. Though both giver and recipient would always carefully maintain the courtly fiction of an even exchange of gifts, such presents were implicitly expected to yield some concrete recompense: Strada had in fact received a quite generous remuneration for the fruits of his labour, disguised as Ehrengeschenk-literally a 'honorarium'. On the other hand, the six monumental volumes of his Series Imperatorum

$51 \quad$ DOC. 1568-11-13; on the Neugebäude, see below, Chapter 9.

$5^{2}$ DOC. 1569-04-oo; On Licinio's frescoes, see Lietzmann 1987, pp. 148-149; on Licinio in general, ibidem p. 148-151, and Vertova 1976, pp. 513-589 and 543-544.

53 DOCS. 1573-01-21; 1574-06-01; 1574-06-08; on Maximilian's attempts to acquire antiques: Lietzmann 1987, pp. 164-166; Brown 1987, which provides additional archival material. 
preserved in the Österreichische Nationalbibliothek appear to have been an explicit commission. Basically they should be regarded as an alternative to the catalogue raisonné of the Imperial coin collection that-as we have seen above-was never realized. It is not known when exactly they were presented to the Emperor, but in December 1575 Strada first applied to be paid for them. He had to repeat this request many times, and only in August of 1577 Rudolf II accorded him 6oo Thaler, exactly the same amount per volume that he had received as Ehrengeschenk for the earlier volumes. ${ }^{54}$ It is not clear whether this sum was actually paid, and it may be that an unusual draft on the revenue of Silesia granted him in November of the same year, for which no motivation is given, represents the payment due to him..$^{55}$ Nonetheless even in the 1580 s Strada still had to sue for payment of his outstanding dues from the Hofkam$m e r$, including both the arrears of his salary and the payment for books provided: the latter referring either to the manuscript volumes of the Series or, perhaps more likely, to books from his studio that he had provided to the Hofbibliothek or to the Emperor, Rudolf II, himself. ${ }^{56}$

\subsubsection{Was this Really All? Locating the Blank Spots on the Map}

Altogether this list is rather modest: in twenty years of service Strada had three times advised on important projects, produced an estimate of a fourth, and rendered an unspecified service in connection with a fifth. He had further provided the Emperor with some antique sculpture, eight important and expensive manuscript volumes from his own workshop and-possibly-some printed books from his studio, for all of which he had been separately paid. The design for the Neugebäude-date and wording of the source strongly suggests that this was probably a general plan, not just a design for a minor detailis the only one of his recorded services that is in keeping with the function he held and the salary he received. Several arguments can be proposed to explain this apparent discrepancy, linked on the one hand to the character of the sources, on the other hand to the character of the services in themselves.

54 DOCS. 1575-12-0o; 1576-05-00; 1576-08-0o; 1577-02-13; 1577-02-18<b>; 1577-03-10; 1577-03-18; 1577-08-02; 1578-10-00; all seem to refer to payment for the same six volumes originally delivered to Maximilian II, for which Rudolf in August 1577 finally accorded a sum of 600 Thaler, but which were not yet actually paid in 1578 .

55 DOC. 1577-11-oo; the grant was probably intended as (part of?) the payment due to Strada for the six books of the Series Imperatorum, though it might refer to other goods-works of art, antiques, books from Strada's Musaeum? - he had purveyed to the Emperor. It cannot refer to his regular salary, since this is all accounted for in the financial deliberations relating to his discharge in 1579 .

$5^{6}$ DOCS. 1579-10-15; 1579-10-30; 1580-04-26(a, b, c); 1580-08-02; 1582-03-28; 1582-06-19. 
In the first place it should be kept in mind that most of the archival data which document Strada's activities at court are taken from the records of the Hofkammer, the financial administration. I have pointed out elsewhere that these in themselves may well be incomplete, since the Emperor disposed of other than purely pecuniary means to materially reward services rendered, such as payments in kind, which Strada at least occasionally received; a consideration that helps to widen the gap between rewards and documented services. ${ }^{57}$ Except for the payment of the two salaries, which are quite regularly entered in the books (though far less punctually discharged, especially towards the end of Maximilian's reign), all registered payments refer to extraordinary expenses, in particular travel allowances and payments for goods provided. This warrants the perhaps rather obvious conclusion that the two salaries Strada received were considered to cover most of his regular services, for which no separate payment was necessary, and of which no account was kept. It also implies that-apart from the books of drawings- he did not provide independent works of art—such as paintings—-produced by himself or in his studio, because these were generally separately paid for. But it does not necessarily exclude that he provided ideas and sketches, or even workedout designs, to be used by other court-artists. And neither does it necessarily exclude that he provided individual objects from his Musaeum-or from his stock-in-trade as a bookseller and art-dealer? - which may have been paid in cash or in some other way in which the identity of the seller remained anonymous.

In the second place it must be pointed out that the dearth of sources on Strada's activities is by no means exceptional: the documentation of the artistic patronage of the Austrians Habsburgs in their own capital is extremely incomplete. Even the genesis of Maximilian's grandest project, the Neugebäude, can only be reconstructed from very incomplete financial sources: it was hardly ever mentioned explicitly even in his own correspondence, as far as known to date. ${ }^{58}$ Until the recent publication of the results of the Hofburg project, it was simply not known when as important an extension of the Hofburg as the Neue Burg or Amalienburg - also known as Ernestinische Trakt, having been originally conceived as the residence of Archduke Ernest - was given its basic architectonic order: dates given in the earlier literature vary between the $1570 \mathrm{~s}$ and the $1620 !^{59}$

57 Jansen 1988<c >; Jansen 1992.

$5^{8}$ On the Neugebäude, see below, Ch. 9 .

59 On the Amalienburg, see now Holzschuh-Hofer 2014 (d); cf. below, Ch. 10.2. 
This appears the more surprising because the dynasty's patronage in Innsbruck is quite well documented, in particular the construction, under Ferdinand I and Maximilian II, of the Hofkirche and the mausoleum for Maximilian I, and the restructuring of Ambras castle for Archduke Ferdinand II of Tirol. Doubtless this is partly due to the professional organization of the Landesregierung at Innsbruck, the government of Tirol, which was often involved (and had to pay); its archive has been well preserved. But it is also due to the frequent absence of its princes: the Emperor resided in Vienna, and though Archduke Ferdinand always had a great affection for the Tirol and was its designate ruler, for sixteen years he served as his father's and brother's governor of the Kingdom of Bohemia. Every decision of any importance was therefore resolved upon only after epistolary consultation with either the Emperor or with the Archduke himself.

For Vienna, as probably for the whole of Lower Austria, such consultation doubtless likewise took place, but in most cases decisions were referred to the Emperor in person, either by those involved themselves or through the mediation of courtiers or agents. Any minutes of such conversation or written notes of instructions would not have the status of official correspondence, so they would not be registered in the chancery, and the originals, being directed at the individuals concerned rather than to a government office, would not be preserved. This means that crucial information about the genesis of the artistic projects at court, such as the motif for their commission, the considerations determining their iconography and well as those influencing their form and style, and the selection of suitable artists, is almost non-existent. ${ }^{60}$

The very fact that Strada's activities at court are so scantily documented strongly suggests that his services belonged to this consultative category. The

6o Only when immediate financial consequences were involved, agreements or decisions would be recorded in writing. Since the Imperial administration-involving a great many authorities - was still far from perfect, such records as preserved are far from complete. The selected excerpts from the sources as published in the Jahrbuch der Kunsthistorische Sammlungen des allerhöchsten Kaiserhauses (JdKS) are a monument of nineteenth-century scholarship. Yet they remain a selection, and many sources have not been taken into consideration: the daunting task of publishing the correspondence of Ferdinand I and Maximilian II, for instance, has never been undertaken (except for two volumes of Maximilian's letters to other members of the dynasty, covering less than four years). Publications such as Walter Pass's Musik und Musiker am Hof Maximilian's II. (1980), Hilda Lietzmann's painstaking monograph on the Neugebäude (1987), Zweder von Martels's biography of the Imperial envoy Ogier Ghislain de Busbecq (1989) and Karl Rudolf's comparison between the patronage at the courts of Vienna and Madrid (1995) have shown that detailed research in the Vienna archives can add considerably to our knowledge. 
gist of the conclusions of the committee sent to Innsbruck to advise on the completion of Maximilian's tomb has been preserved, not because of the importance of the enterprise, but because the Emperor happened to be absent from Vienna, and because it had to be communicated to the relevant authorities in loco. Otherwise their full report would have been made in a personal interview with the Emperor and perhaps both his elder sons; the discussion would then have been supported by a file of relevant material including earlier designs, sketches of alternative solutions, brouillons of the proposed iconography, and perhaps some comparative material. As similar package of documentation about the Innsbruck tomb was compiled by Schallautzer on an earlier occasion, which is documented only because it had had to be sent to Ferdinand, who happened to be absent. ${ }^{61}$

The same holds for Strada's involvement in the conception of Ferdinand's tomb in Prague: we know that he went there, but his conclusions again must have been communicated to Maximilian in person and - one must presumewere taken into consideration when further plans were made. A case can be made that he was paid his two annuities chiefly in order to provide such advice: advice which, because of his education, his cosmopolitan erudition, his artistic expertise and - not least-his disposal of the treasures assembled in his Musaeum, he was perfectly qualified to give. In the following paragraphs two examples will be given where circumstantial evidence allows an interpretation of the scanty or even non-existent formal, administrative evidence of Strada's role.

\subsubsection{An Example: The Ceiling of the Goldener Saal at Innsbruck}

A document preserved in Innsbruck that has not yet been considered gives a perfect example of Strada being active in this consultative capacity without receiving any specific remuneration. This is a letter by Hermes Schallautzer to the Emperor, dated 16 July $1559 .{ }^{62}$ It responds to an instruction received from the Emperor dated 8 June 1559, from Augsburg, where Ferdinand was presiding the Imperial Diet. The Emperor had sent Schallautzer a drawing ('Vysierung') of the 'Neue Sallpoden', the ceiling of the great hall of the Hofburg in Innsbruck. This hall, known as the Goldener Saal, had been restructured in a moderate Renaissance idiom by the Italian architect Lucio Spazio, shortly after a fire had destroyed part of this Imperial residence in 1534. It had been provided with windows by Paul Dax in 1538-1540, but its decoration had never been completed: perhaps just because Ferdinand was very fond of Innsbruck

61 Cf below, Ch. 6.2.

62 DOC. 1559-07-16. 


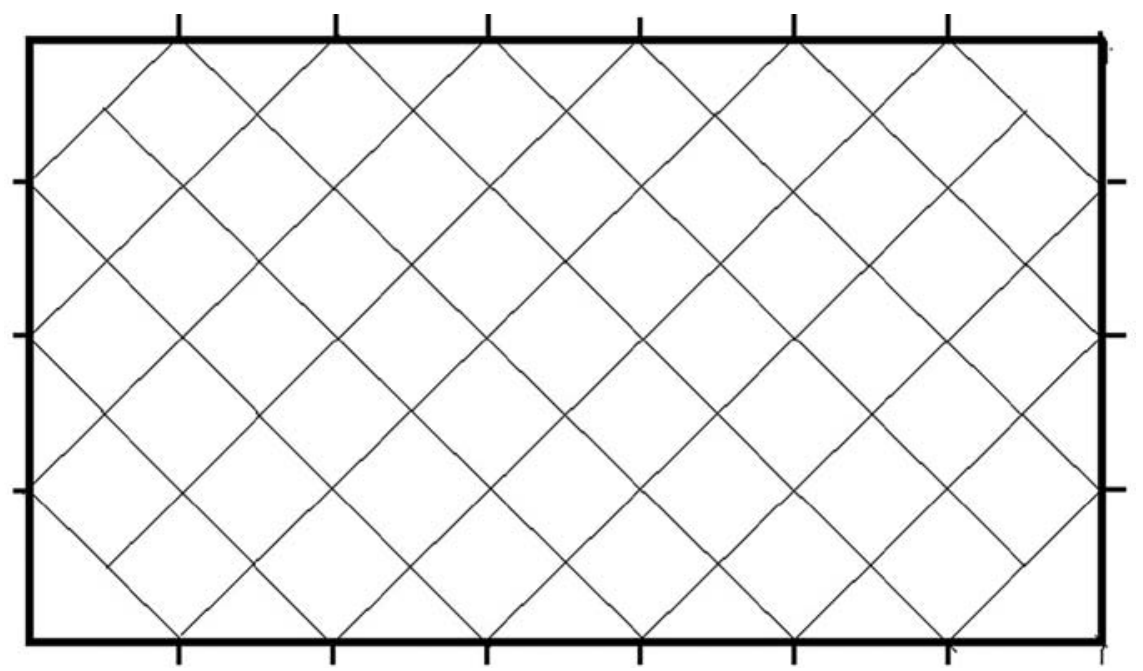

FIGURE 4.12 A hypothetical reconstruction of the earlier version of the lay-out of the ceiling of the Goldene Saal in the Innsbruck Hofburg. Planned to consist of sixty-three diagonally placed 'square and pointed' panels, it was later modified to a more monumental one, in which thirty-five larger panels offered greater scope for the planned 'fantasies' that Domenico Pozzo was to paint in them.

he appears to have found it difficult to make up his mind. At one time he had asked Anton Fugger to suggest a name of a competent painter to provide an advice as to its decoration, and in $155^{\circ}$ no fewer than three painters, Christoph Amberger, Hans Kels and Heinrich Kron, had actually presented drawings for the project. ${ }^{63}$

Though already in 1555 a definitive decision on its decoration appears to have been taken, only now concrete steps were taken to execute it, to which purpose Schallautzer was instructed to summon the painter Domenico Pozzo. It is not known when this Milanese painter had entered Ferdinand's service; he worked mostly in Innsbruck, where he painted the Annunciation on the shutters of the famous organ by Jörg Ebert in the Hofkirche. Later he would work also in Vienna and Prague. ${ }^{64}$ But at the time he appears to have been workingprobably for King Maximilian-in the Imperial hunting lodge at Kaiserebersdorf. Certainly it was from there that Schallautzer summoned him to hear Ferdinand's instructions, to show him the enclosed 'Vysierung'-doubtless a schematic drawing showing the division of the ceiling - and to commission him ' $<$... $>$ das er in allen gevierte und gespitzte Feldung ein sonndere fein

63 Fellmayer / Oettinger / Scheicher 1986, p. 63.

64 Thieme-Becker 26, p. 32; Dreger 1914, p. 115; Podewils 1992, p. 257-58. 
fantesey mache, auch auf underschidliche papier verfassen $<. . .>$ '. This appears to indicate that the ceiling - it was a timber 'Poden', rather than a vault in masonry (which would have been indicated with the term 'Gewölb')—consisted of diagonally placed square compartments, leaving space for smaller triangular section along its margins (the 'gespitzte Feldung'). This ceiling consisted of sixty-three of such compartments, and may have looked somewhat like the hypothetical reconstruction offered here [Fig. 4.12]. For each of these panels Pozzo was expected to invent a 'fantasy' and make a drawing of it on a separate sheet. ${ }^{65}$ When finished, Schallautzer and Pozzo were to negotiate a price for the execution of the paintings and the expense of the colours and the gilding, after which the painter was to be dispatched, taking his drawings with him, to the Emperor, who then could take his final decision.

Pozzo appears to have had a ready imagination, if he could think out his scheme and conceive no less than sixty-three 'Fantesey' or inventions, within the two weeks at most at his disposal. This rather suggests that he was forewarned, and of course it is perfectly possible that a project of such importance and of such long standing had been discussed informally beforehand. Certainly the time was too short to produce sixty-three fully worked out designs for each of the fantasies: Pozzo therefore proposed to draw a limited number of views showing sections of the projected ceiling in which he sketched his proposed inventions for each compartment. Schallautzer agreed to this proposal on the condition that Pozzo would work out one of the compositions in a full-size drawing, 'wie es ins werck sein soll'.66 Since Schallautzer uses the

65 A ceiling of a double square can be divided in forty-five diagonally placed square compartments, which gives 14 triangles (each half the square compartments) at the margins and four larger triangles (two combined marginal triangles) in the corners, which adds up to sixty-three compartments in all. There appears to be no graphic documentation of the Goldener Saal before the mid-eighteenth century, but an (approximate) proportion of a double square for (the principal section of) the hall is not contradicted by the preserved plans (Felmayer / Oettinger / Scheicher 1986, pl. 48a). The ceiling was carried on carved stone corbels ('geschnittne krackstain'): the number of compartments was later reduced, which could not have been done in the compartmented ceiling in carpentry typical of the German Renaissance, so it must have been either a flat timber ceiling — the most likely option - or possibly a light (slightly curved?) stucco ceiling hanging from the beams; except for the corbel-stones and the Imperial coat of arms in the central compartment, it included no carved or moulded elements: the gilding used was just gold-paint ('ringiltigen farben') (JdKS 11, 1890, II, p. ccxxII, Regest 7762, discussed below).

66 The text of the letter allows various interpretations: on the one hand it is possible that Pozzo did indeed produce sixty-three individual sheets, but that these were merely quick sketches, instead of detailed modelli in which the proposed shading was indicated in wash. On the other hand he may also have produced one large overview of the ceiling as a whole, in which each invention was sketched; but since his proposed inventions were 
term 'zumallen' - 'to paint' rather than 'to draw' - this drawing certainly was a detailed modello, probably executed in watercolours or gouache to indicate the proposed colouring, and it was added to the file Pozzo was to carry with him to the Emperor.

Through his long experience as Bausuperintendent, Schallautzer had acquired considerable competence in architectural matters, but he did not pretend to any specific expertise in the pictorial arts. At least two of the Italian architects he employed at court had received their initial training in that field, Pietro Ferrabosco and Jacopo Strada. Before Schallautzer sent Pozzo to the Emperor, he decided to ask these two masters to critically examine the artist's proposals. After conferring together, the three instructed Pozzo to make some changes in several of his sketches and to completely redraw some others. Only after Pozzo had carried out these changes and an agreement concerning remuneration and expenses had been negotiated did Schallautzer sit down to draft his covering letter to the Emperor.

Ferdinand appears to have been content with the result, since he immediately wrote to the Innsbruck authorities to acquaint them with its details, repeating much of the contents of Schallautzer's letter. It indicated that Ferdinand intended 'weder in die gefierten noch gespitzten veldungen von conterfehung wappen oder rosetten ze stellen, nit sonder von allerlai ander vantaseien darein malen ze lassen': i.e. instead of decorating the square and pointed compartments of the ceiling with the habitual rosettes or coats of arms, he wished to have them filled with various painted 'fantasies' ${ }^{67}$ Before the end of the year Pozzo had begun painting these fantasies, which satisfied the Emperor sufficiently to extend further commissions to him, all in Innsbruck. ${ }^{68}$ Yet it appears that before Pozzo started painting, various further changes were discussed, probably now in the presence of the Emperor himself, who had returned to Vienna early in September. Chief among these was the reduction of

sufficiently detailed for Ferrabosco and Strada to comment on them individually, and to suggest individual alterations and in some cases to have them completely redone, this is far less likely.

67 Letter of 28 July 1559, TLA, KS 8o1; excerpt printed in $J d K S$ 11, 1890, II, p. CLXXXIII, Regest 7366.

68 In 1560 and 1561 , Pozzo was commissioned to paint the various biblical scenes decorating the case, as well as the two large wings closing the splendid organ (1560) by Jorg Ebert in the Hofkirche, the church built next to the Hofburg to house the sumptuous mausoleum of Maximilian I; next, in 1561, he painted the decoration of the vaulting of the cloister in the Neuen Stift, the Franciscan monastery annex to the Hofkirche, and finally, in the same year, an altarpiece for one of the principal altars in the same church (Felmayer/Oettinger/Scheicher 1986, pp. 242-243 and 280-283; only the decoration of the organ (illustrated ibid., Figs. 374-367) has been preserved. 
the number of compartments to thirty-five, including a central compartment containing the Imperial coat of arms held by two gilt griffins. The consequent larger size of the panels made them more suitable for the planned 'vantaseyen': these were not grotesques, as the term might suggest, but a set of depictions of 'die historien weilend kaiser Maximilianen und ains tails kaiser Karls hochlobichisten gedechtnussen schlachten', scenes from the life of Maximilian I and some of Charles v's battles. Further changes were only undertaken after Pozzo had arrived in Innsbruck, and it turned out that the Visierung on which he had based his drawings had not been sufficiently detailed: the brackets carrying the ceiling had not been indicated, so he had to plan a different, wider border section; for the extra work involved in this, and some further changes in the fantasies themselves, he received some additional payment. ${ }^{69}$

Though the documents relating to this project suggest several questions that cannot be easily answered, they still throw some light on the handling of artistic commissions at the Imperial court. The commission was an important one: as the principal decoration of the principal room of one of the principal Imperial residences, it had great representative value, the more so since it would be about the first example of Imperial splendour inspected by any Italian prince, prelate or envoy visiting Habsburg territory. From Schallautzer's letter it appears unlikely that Ferdinand's directions, or the accompanying Visierung, had included any specific iconographical instructions: Schallautzer certainly would have referred to that. The use of the word 'Fantesey' can be stretched to suggest that Ferdinand himself had indicated that some secular, literary or historical theme was intended, and it is quite possible that the scenes from the life of Maximilian I and the battles of Charles $\mathrm{V}$ actually painted were envisaged from the outset. Documentation on the former-Dürer's Ehrenpforte in the first place-was available in any case because of the contemporary planning of Maximilian's tomb, likewise decorated with his principal gesta. Certainly the letter implies that Ferdinand had great confidence that Pozzo was capable of coming up with a series of subjects suitable for the location.

Schallautzer's letter provides a lively vignette of the day to day tasks of the leading artists at court. Imagine a lively discussion taking place on a hot summer day - it can be stifling in Vienna - conducted in German spoken with a Viennese and two different Italian accents, and possibly partly in Italian translated by Strada or Ferrabosco for Schallautzer's benefit; moreover garnered with Italian and Latin quotations. Imagine this discussion taking place around a table covered in drawings piled about one central plan-the 'Vysierung'

69 Advice of the Tirol government to the Emperor on Pozzo's request for additional payment, 28 January 1564, printed in JdKS 11, 1890, II, p. CCXXII, Regest 7762. 
mentioned in the letter - and probably complemented with a stack of booksClassical and Italian literary texts, Classical mythology, Classical and Habsburg history, emblem books, Dürer prints - to be used as tools of reference. Some previous discussions had doubtless taken place: Pozzo had been informed in detail about the Emperor's wishes, and when inviting his two Italian architects Schallautzer likewise must have explained the project to them. Moreover, if the scenes from the life of Maximilian I had been intended from the start, it is likely that Strada had been consulted beforehand. It can hardly be assumed that Pozzo could have invented and correctly executed no less that sixty-three such scenes without outside assistance, and Strada would have been the obvious person to consult, in view of his historical expertise and the fact that he could communicate his opinion in the painter's native language.

During the discussion itself Strada would probably have had the leading voice. Though Schallautzer was a well-read amateur antiquary and doubtless well acquainted with recent Habsburg historiography, Strada's historical erudition, based as it was on his first-hand research under Hans Jakob Fugger's mentorship, at the very least must have equalled it. Moreover Schallautzer himself pretended no competence in artistic matters, and Ferrabosco's expertise, based on his early training as a painter, was no match for Strada's extensive and up-to-date knowledge of comparable decorative schemes in principal centres of artistic creation such as Rome, Mantua and Venice; expertise he could moreover support with the graphic materials documenting such schemes he had in his possession-including Dürer's Ehrenpforte. ${ }^{70}$

The only reason we know about this discussion was the absence of the Emperor from Vienna, to whom Schallautzer had to report in writing. The only reason we know that further changes were made after Ferdinand had returned to his capital, is that Pozzo, years later, applied for some additional recompense in view of the extra work these had entailed. Except from regular reference to payments made to the artist in the course of his work, the sources are silent on the project, and therefore no definite conclusion on the responsibility for these changes can be drawn. Yet it is not very difficult to conjecture that Strada had a hand in these. It can be assumed that when Ferdinand returned to Vienna after his long absence he received his principal servants in audience, to hear their reports on current affairs. The progress on Imperial architectural commissions would have been reported by his Bausuperintendent, Hermes Schallautzer, and it would be surprising had no mention been made of the Innsbruck ceiling. If Ferdinand still had doubts about it, he could naturally consult the members of the committee that had prepared the recent Gutachten about the ceiling. On 
the other hand it may well be that Strada referred to the project and aired any misgivings he may have had. In any case the project was discussed again, perhaps even in a meeting which included the Emperor himself as well as his three consultants - Schallautzer, Ferrabosco and Strada - and the painter. The discussion resulted in the reduction of the number of compartments from sixtythree to thirty-five, including a central compartment with the Imperial coat of arms. This change allowed more space to each of the-fewer-individual scenes: the consequent larger scale of the figures resulted in more monumental compositions, while the less cluttered architectonic order of the ceiling increased the monumental character of the decorative scheme as a whole. It is very tempting to attribute the initiative for this change to Strada, who was best acquainted with these qualities as present in recent developments in Italy and, as we have seen, could support his point of view by the graphic documentation contained in his Musaeum.

\subsubsection{Another Example: Contribution to the Organisation and Design of Festivals}

Strada's contribution to the design of the ceiling of the Goldene Saal is documented by at least one formal document from its patron's archives. This is not the case for his possible contribution to the realization of the various festivities that were organized at the Imperial court in his time, though at present it is accepted that he must have been at least occasionally involved in these. ${ }^{71}$ The most tangible reason for this supposition is the set of festival designs from Strada's workshop that have been preserved among his miscellaneous papers in the third volume of the Codex miniatus 21 in the Nationalbibliothek in Vienna. One of these, an elegantly dressed-up elephant, is provided with an annotation in the hand of Ottavio Strada: 'the elephant was dressed for the wedding of Archduke Charles, invention of my father' [Fig. 4.13]. ${ }^{72}$

71 Basic information on the festivities at the court of the Austrian Habsburgs in Wir sind Helden 2005, which provided an extensive, yet incomplete bibliography of earlier literature (pp. 171-176), in which Strada is not mentioned. Strada's contributions generally discussed the context of his few preserved costume designs and their relation to Arcimboldo's: Kaufmann 1978<a>, Chs. I-III; O’Dell 1990; Kaufmann 2009, pp. 78-80; Kaufmann 2010; Kárpáti 2012.

72 'Così fu vestito l'Elephante per le nozze del Ser.mo Archiduca Carlo, inventione di mio padre'; the festival drawings are found in öNB-HS, Cod. Min. 21,3, fols. 316/33-343/6o (interspersed with a few antiquarian drawings); the elephant is found on fol. 366/74. It should be noted that it is not certain that these volumes belong to the former holdings of the Vienna Hofbibliothek, much less to Rudolf's Kunstkammer, as a note on fol. 46o/19o of this volume refers to an earlier owner of at least part of the material: 'Seindt in disen Buch gerissen Pletter und Khunstuckh $<$ sic $>$ Pey Hand 230 Stuckh. 1629. Jars / CS $<$ for 


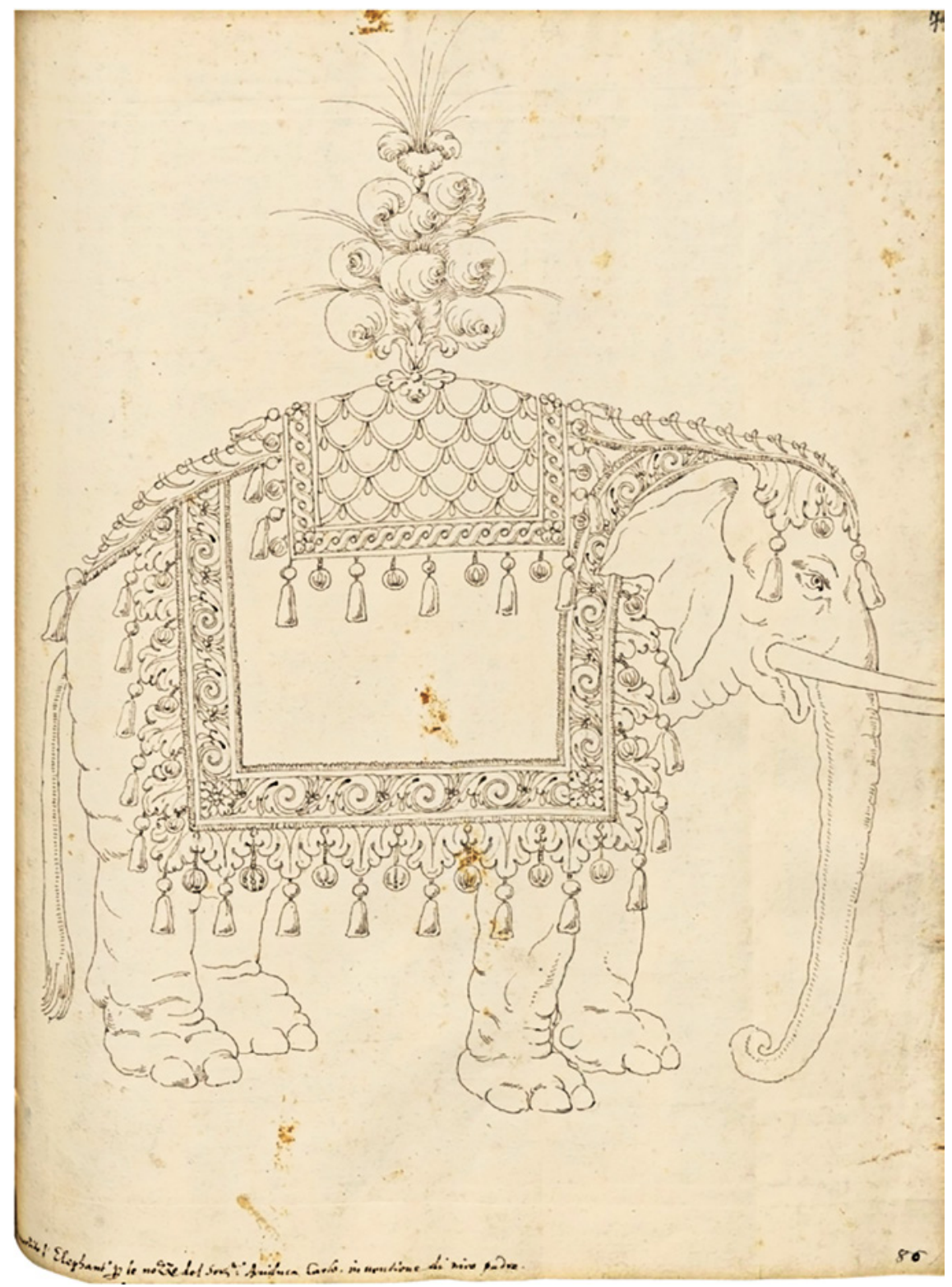

FIGURE 4.13 Jacopo Strada, design for the accoutrement of an elephant used in the festivities at the wedding of Archduke Charles, 1571; Vienna, Österreichische Nationalbibliothek, Cod. min. 21,3, fols. 74 . 

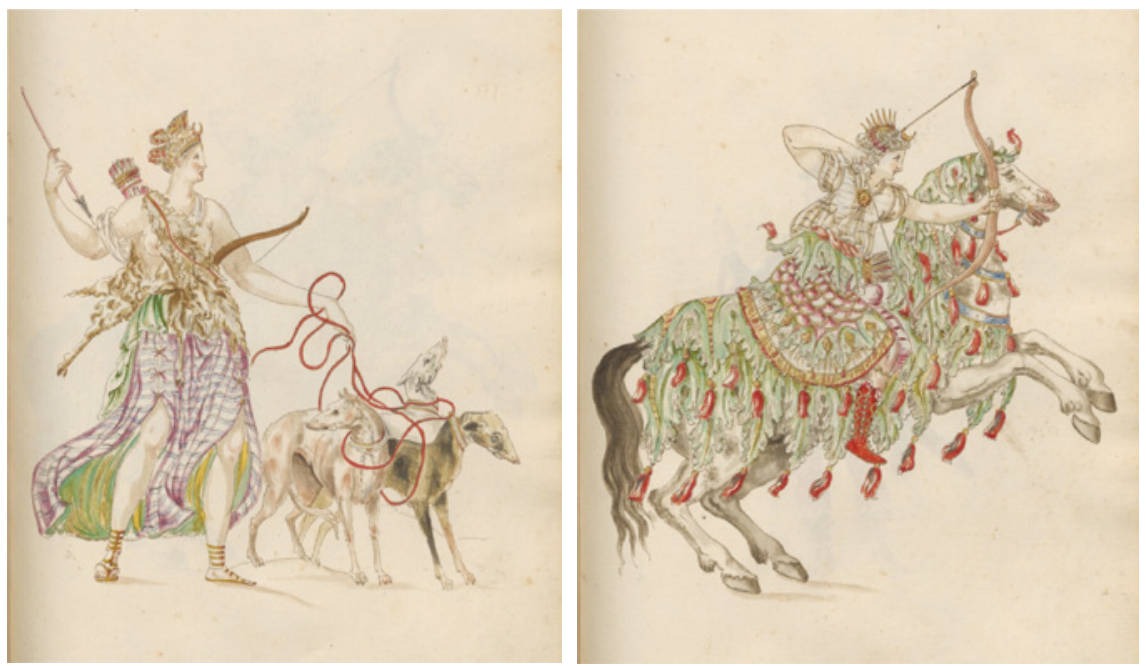

FIGURES 4.14-4.15 Jacopo Strada, Diana, designs for the costumes of a pedestrian and an equestrian version of the Goddess participating in court festivities; all Vienna, Österreichische Nationalbibliothek, Cod. min. 21,3, fols. 41-42.

If this information is correct - and there is no reason why it should not beStrada at least on one occasion did provide a design used or to be used in one of the more important festivals at the Imperial court during Maximilian II's reign. Strada himself at a later date vaunted his competence in this field, when he offered his services to Archduke Ernest, after he had resigned his functions as architect and antiquary to Rudolf II: 'I can also serve in having made ["far fare"] inventions for masques, tourneys and other beautiful things such as may occur to your Most Serene Highness. ${ }^{73}$

The Archduke would have been perfectly aware of this, having known Strada all his life and counting his elder son Paolo among his gentlemen of the chamber. But apart from Ottavio's comment on the elephant design, the only direct written evidence we have that Strada was involved in organizing or designing — or both—of such events, is a reference to the festivities organised in September 1572 in Pressburg/Bratislava, on the occasion of the coronation

Christoph?>. Ranfft d. Elter von Wiessendal.' It is suggestive that 1629 is the year of death of Anna Maria Strada, Ottavio's illegitimate daughter and one time mistress of Rudolf II, who doubtless left her estate to her husband, Christoph Ranfft von Wiesenthal, and their children (her children by Rudolf II had predeceased her without issue); cf. Sapper 1999.

73 DOC. 1579-05-00: 'Posso anche servire in far fare inventioni per mascherate, per tornei et altre belle cose come alla giornata puole occorere a Vostra Altezza Serenissima'. The letter is discussed in greater detail below, Ch. 4.4.1. 
of Archduke Rudolf as King of Hungary. ${ }^{74}$ The reference is in a letter of 3 September 1572 written by the Mantuan envoy, Emilio Stanghellino, to Guglielmo Gonzaga, Duke of Mantua. Stanghellino had referred to the preparations for this festival in earlier letters, recording that Maximilian had sent Francesco Gabrino or Caprino, his 'mozzo da camera' or groom of the chamber, to Milan to acquire precious fabrics for the costumes. Now he told the Duke that:

Our own Strada from Mantua, as antiquary, has been given the charge to have made the costumes, sashes ['girelli'] and surcoats for the jousts of the most serene princes, which will be made after the model of ancient armour, but they will result to be quite beautiful and rich, the fabrics being fine [cloth of] gold and silver, with very little silk; and they will be trimmed with most beautiful embroidery and gold fringes. ${ }^{75}$

The splendour of this particular entertainment is documented elsewhere, for instance in Stephanus Pighius' Hercules prodicius of 1587: a memorial for his pupil, Maximilian II's nephew, Prince Karl Friedrich of Cleves, who had participated in the festival and won several of its prizes. The prince's entry into the running at the ring of 27 September was singled out by Stanghellino:

The prince of Cleves was armed in the manner of the ancient Romans ['armata all'antica romana'] with costumes so rich in brocades, cloth of gold, embroidery, and with a company of horse completely covered in cloth of gold and silver, and the horsemen dressed so pleasantly and with such elegance, that he rightly obtained the prize.

Karl Friedrich and the members of his suite ('comitatus') were not the only participants who dressed themselves in classical style. In the same letter Stanghellino relates the entry of two other of Maximilian's nephews, the princes Wilhelm and Ferdinand of Bavaria, who presented themselves and their suite in 'a livery in crimson and white, of brocade and velvet, superbly ornamented and very well accompanied', under the Ovidian motto Tempus edax rerum: 'Time, the devourer of all things'. In his description Pighius related that:

$<\ldots>$ each and every person's costume was matched so elegantly to him with colours, symbols and appropriate emblems on shields, taken from

74 An overview of the sources of this festival in Lietzmann 1992, pp. 84-101; contemporary printed description in Solennissime Feste 1572 and Pighius 1587, pp. 183-189; see Lindell 1988; Kaufmann 2010, pp. 180-185.

DOC. 1572-09-26 / Venturini 2002, p. 221, no. 102. 
ancient sculpture and coins, that everyone could be easily recognized and the whole story and plot be understood from the ornaments and trappings. ${ }^{76}$

Both Stanghellino's reference to the armour 'all'antica Romana' and the sources for the designs mentioned by Pighius strongly suggest that Strada had been involved in the preparations of the festivities by virtue of his antiquarian knowledge and his collection of visual documentation of many aspects of Antiquity, including ample material on the warfare of the Romans. Stanghellino's formula, 'Il Strada nostro Mantovano, come antiquario' [italics mine] even suggests that such was considered a natural component of his function at court.

Stanghellino explicitly says that Strada was given the charge to have made ['far fare'] the costumes for this festival. This suggests not necessarily the making of all the individual designs, but rather the organizing and supervising of both the designing and the manufacturing process of the costumes and perhaps the decorations. The relatively brief time in which such festivities were organized in general, and the scale of this entertainment in particular suggest that all available intellectual, literary, musical and artistic talent was recruited to participate in the preparations. ${ }^{77}$ It is doubtful that there was one single 'author' or director of the festival, providing both the argument and a detailed planning of the iconography. It is much more likely that it was prepared by a commission reuniting the various competences, and presided over by a highranking courtier (such as the Master of the Horse) or perhaps even one of the members of the dynasty (in this case Archduke Ernest is the most obvious candidate). As expert antiquary Strada would have had a voice in this commission, as would have other artists (such as Giuseppe Arcimboldo), literati (such as Giovanni Battista Fonteo) and musicians (such as Philippe de Monte) who had ample experience with similar commissions. And then one should count in the Imperial Heralds, the Gentlemen of the Imperial Chamber and Stable and

76 Venturini 2002, p. 222, nr. 104: 'Comparvero gli eccellentissimi duchi di Baviera con livrea carmosina e bianca, di broccato et velluto, superbamente guarniti e benissimi accompagnati, con il motto Tempus edax rerum'; Pighius 1587, p. 188; Lindell 1988, p. 347; translation taken from Kaufmann 2010, pp. 183-185.

77 On 3 September Stanghellino reports to Duke Guglielmo from Vienna that 'at present nobody thinks of anything else but to prepare arms and horses, costumes and liveries, for the occasion of these festivities, having already forwarded [to Pressburg] artillery, munitions and everything necessary for the settings ["apparecchio"] of the wooden city they are planning, as I have written earlier<...>' (Venturini 2002, p. 221, nr. 102). A similar point is made in Larsson 2000. 
the commanders of the detachments of infantry, cavalry and ordnance who decided upon the ceremonial and military aspects of the entertainment. ${ }^{78}$

Doubtless not all of the thousands of soldiers that were to participate in the combat scheduled for the third day of the festivities will have been dressed in cloth of gold: yet they had to be provided with some sort of garment and arms to be able to defend or conquer the two temporary fortified towns-defended by three hundred cannon! - which Pietro Ferrabosco had had constructed on the banks of the Danube just outside of Pressburg - Ferrabosco told Stanghellino that the wood from which these were built alone had cost about six thousand gulden. ${ }^{79}$ Such elaborate settings were designed by professionals such as Ferrabosco according to some general scenario for the entertainment, but the design of costumes and trappings cannot have been coordinated in minute detail, given that the participants themselves had some say in the matter, and had to pay for their costumes. Thus Pighius relates that his pupil Karl Friedrich spent four thousand ducats on his entry. He moreover implies that he himself, with Hugo Blotius, had advised the prince on an allegorical theme derived from Roman Antiquity, 'not without its use to inflame in a young prince the love of virtue'. Its link with Antiquity was strengthened by the 'fictive name', Julius Clivimontius, under which the prince entered the lists-a transparent pun on his family's titles as Dukes of Jülich, Cleves and Berg. ${ }^{80}$

It is not inconceivable that Pighius, a humanist and antiquary who had some experience as a draughtsman, also provided some of the sketches for his pupil's entry. ${ }^{81}$ On the other hand they may well have turned to Strada: Pighius mentioned him among the luminaries of Maximilian's court, so it can be assumed that he and his pupil profited from Strada's conversation and visited

78 That the various learned and artistic disciplines overlapped sometimes, and that Strada at least was aware of other artistic endeavours at court, is clear when in 1568 he successfully mediated for a famous Italian company of comic actors, the Compagnia dei Disiosi led by Zan (Giovanni) Ganassa (DOC. 1569-01-29; cf. Schindler 2004, p. 312; Schindler 2006, p. 336).

79 Venturini 2002, p. 220, nr. 99 (where Ferrabosco is called 'Parabosco').

8o Pighius 1585, p. 186-187: 'Princeps autem Carulus non inter extremos censeri volens, arctaq. sanguinis, atque amicitiae necessitudine sibi iuncti, Regis solemnem diem honorare haud mediocriter cupiens, non sumptibus pepercit ullis, et aureorum quatuor milia in ludos, ac pompam equestrem expenderen non detrectavit'. It remains to be decided in how far Pighius whispered suggestions into the ear of his seventeen-year old pupil.

81 Pighius 1585, p. 188: 'Sed nolo diutius evagari in huius pompae descriptione, quandoquidem de Corona Pighius illam graphicè suis coloribus depinxerit, et symbola vestium, clypeorumque hieroglyphica diligenter explicavit Caruli principis iussu.' This probably refers to some graphic documentation after the fact, but even then it suggests that Pighius, who was a draughtsman as well as a scholar, may have provided sketches for Duke Charles' entry. 

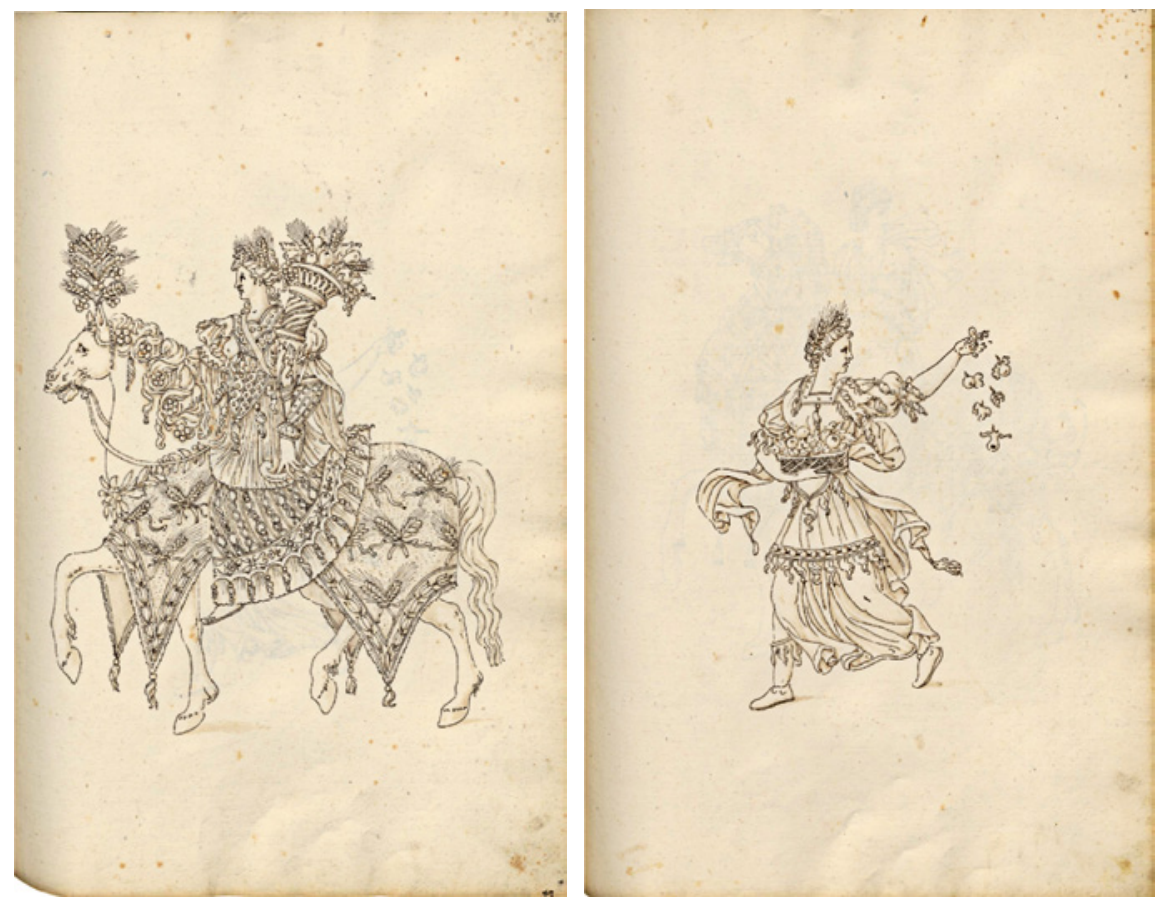

FIGURES 4.16-4.17 Jacopo Strada, Ceres and one of her attendants, designs for the costumes of an entry in the 1572 festival at Pressburg; Vienna, Österreichische Nationalbibliothek, Cod. min. 21,3 , fols. $35^{-3}$.

his Musaeum. ${ }^{82}$ If he was in charge of the manufacture of the costumes of the Imperial party, it would be convenient to ask him also to provide those of the prince of Cleves. On the other hand he was not responsible for the costumes for the contingent of the Bavarian princes, who arrived in Vienna only three weeks before the coronation, and had brought their own garb, which had been likewise specially designed for the occasion. Whether they had received instructions as to the themes to be represented remains an open question. ${ }^{83}$

Some of Strada's festival drawings can be connected to this festival, such as the Ceres on horseback [Fig. 4.16], which may be a design for that goddess

$82 \quad$ Strada may have tactfully reminded the prince of the hospitality the Strada family had accorded his ancestor, Duke Johann I of Cleves, during his visit to Mantua a century earlier (above, Ch. 1). Pighius was an old acquaintance: himself a learned antiquary and-as Marcello Cervini's secretary—present in Rome during Strada's stay in the 1550s, he would certainly have frequented Strada's studio and doubtless brought his pupil with him.

83 This seems unlikely, but it is not impossible that the theme of the entry and the number of participants and their characters was discussed beforehand in correspondence, through Hans Jakob Fugger or the Bavarian representative at the Imperial court. Lietzmann 1992, p. 79 , note 95 shows that vestments and armour were prepared beforehand in Munich. 

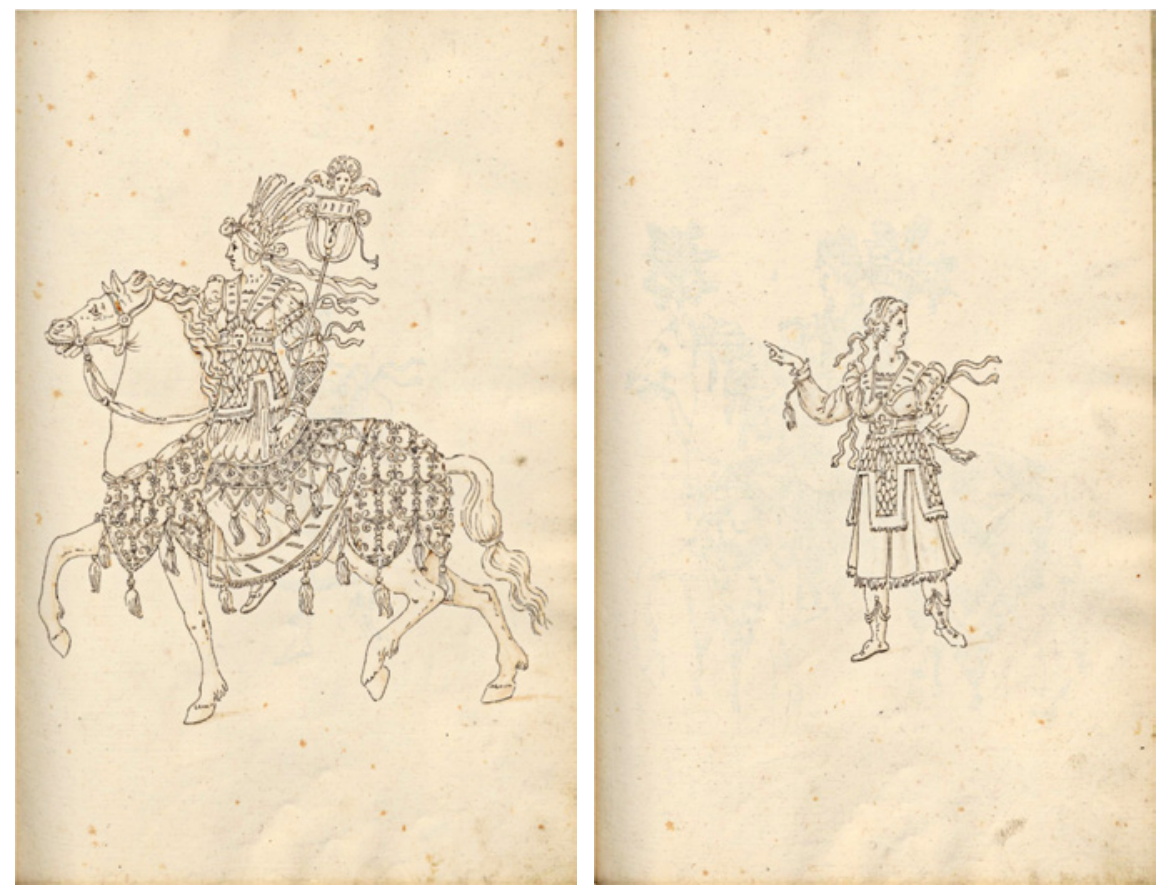

FIGURES 4.18-4.19 Jacopo Strada, Europa, and a Moorish woman, designs for the costumes of an entry in the 1571 Vienna festival; Vienna, Österreichische Nationalbibliothek, Cod. min. 21,3, fols. 33-34.

in the entry of Karl Friedrich of Cleves, while a figure on foot with a similar headdress scattering fruits and flowers may be a design for one of Ceres' or Pomona's followers in the same entry [Fig. 4.17]. Others, such as the two $D i$ anas, on horseback and on foot [Figs. 4.14-4.15], the Europa and the Moorish Woman [Figs. 4.18-4.19] have been identified with figures from the 1571 festival on the occasion of the wedding of Archduke Charles and Maria of Bavaria, the same occasion for which Strada designed the dressed-up elephant. ${ }^{84}$ Here I will not speculate on such identifications, not only because the information about the various festivals is as yet insufficient, but also because the function of the drawings in Vienna is not clear. Their location among other remnants of material such as Strada and his workshop included in the various libri di disegni intended for the Kunstkammer of his patrons, strongly suggest that they document elements of the decorations after the fact. Their state of preservation and the manner in which they are drawn suggest that they are copied from the original designs either by Strada himself and by his son Ottavio or by other draughtsmen in his workshop.

84 Kaufmann 1976, pp. 61-63 and passim, modified in Kaufmann 2010. 
Likewise this must have been the case for two separate volumes of similar copies of festival designs from Strada's workshop, which have been identified recently in the Kupferstich-Kabinett in Dresden. ${ }^{85}$ Both volumes reproduce several of the same inventions found in the Vienna volume; the more voluminous one contains a title page and ninety-nine designs carefully drawn in pen, brown ink and a light yellow/brown wash [Fig. 4.20-4.22]. The title describes these costumes as 'antique', 'Greek' and 'Roman' equestrian statues, but also refers specifically to their use in a festival context. The designs are certainly not directly based on antique sources, but document costume designs for contemporary festivals - witness the drawings for musicians and for figures in fanciful medieval or oriental garb. Just like Strada's numismatic albums, of a similar lay-out and style, this volume was certainly intended for a patron's library, rather than for an artist's workshop.

This supposition of their documentary function is corroborated by the existence of a number of woodcuts by Jost Amman of 'Stattliche Mummereien / so vor zeiten grosse Potentaten gehabt haben' [Fig. 4.23-4.25]. Two of these are based on designs also present among the Vienna drawings [cf. 4.18-4.19]. Ilse O'Dell, who first published these woodcuts, did not know the Vienna drawings. She nevertheless linked the prints to the Stradas, because of the contract drawn up in November 1574 between Ottavio Strada and the engraver, who was to cut no less than two hundred of such 'Mummereyen. ${ }^{86}$ It is not quite clear in

85 These two volumes were identified by Gudula Metze, curator at the Kupferstich-Kabinett Dresden, who signalled them to Thomas DaCosta Kaufmann. I am grateful to Prof. Kaufmann for suggesting that I be informed, and to Dr Metze for showing the material to me at short notice, for discussing it with me and for allowing me to include a first brief appraisal here. The volumes were mentioned earlier in Hölscher / Schnitzer 2000, pp. 133-134 cat. nr. 42 and Melzer 2010, pp. 441, without mentioning their provenance from Strada's workshop. SKD-KK, inv. nr. Ca 93: Equestrium statuarum, tam virorum quam mulierum, formae elegantissimae, una cum vestimentis ipsorum acu artificiosissimae pictis et arte Phrigionica ingeniöse elaboratis, quibus olim induebantur, item cataphractorum equorum cum eorum phaleris ornatissimis, quemadmodum olim Romani et Graeci in bellis atque etiam pompis publicis et ludis curulibus circensibusque usi sunt, iuxtaque ipsos satellitum praecedentium quoque eiusmodi vestibus indutorum formae; his quoque larvarum atque vestimentorum histrionicorum, quibus antiquitus in tripudiis et saltationibus noctu utebantur, varia genera adiuncta sunt; a folio volume including a title page and 99 drawings in pen and brown ink and a light brown/yellow wash of various inventions for festival costumes; SKD-KK, inv. nr. Ca 94: untitled; a folio volume containing 30 drawings in pen and black ink reproducing various inventions for festival costumes. Both volumes reproduce many inventions also included among Strada's Vienna festival designs. A brief note by Dr Metze and myself on these and some other books of antiquarian drawings from Strada's workshop in Dresden is forthcoming in an Italian Festschrift.

86 O'Dell 1990, who provides a full transcription of the document (p. 244) and reproduces all of the twenty-one surviving woodcuts. They are now also available in the relevant volume of Hollstein's corpus of German prints: Seelig 2003, nrs. 215/1-154, pp. 198-236. 


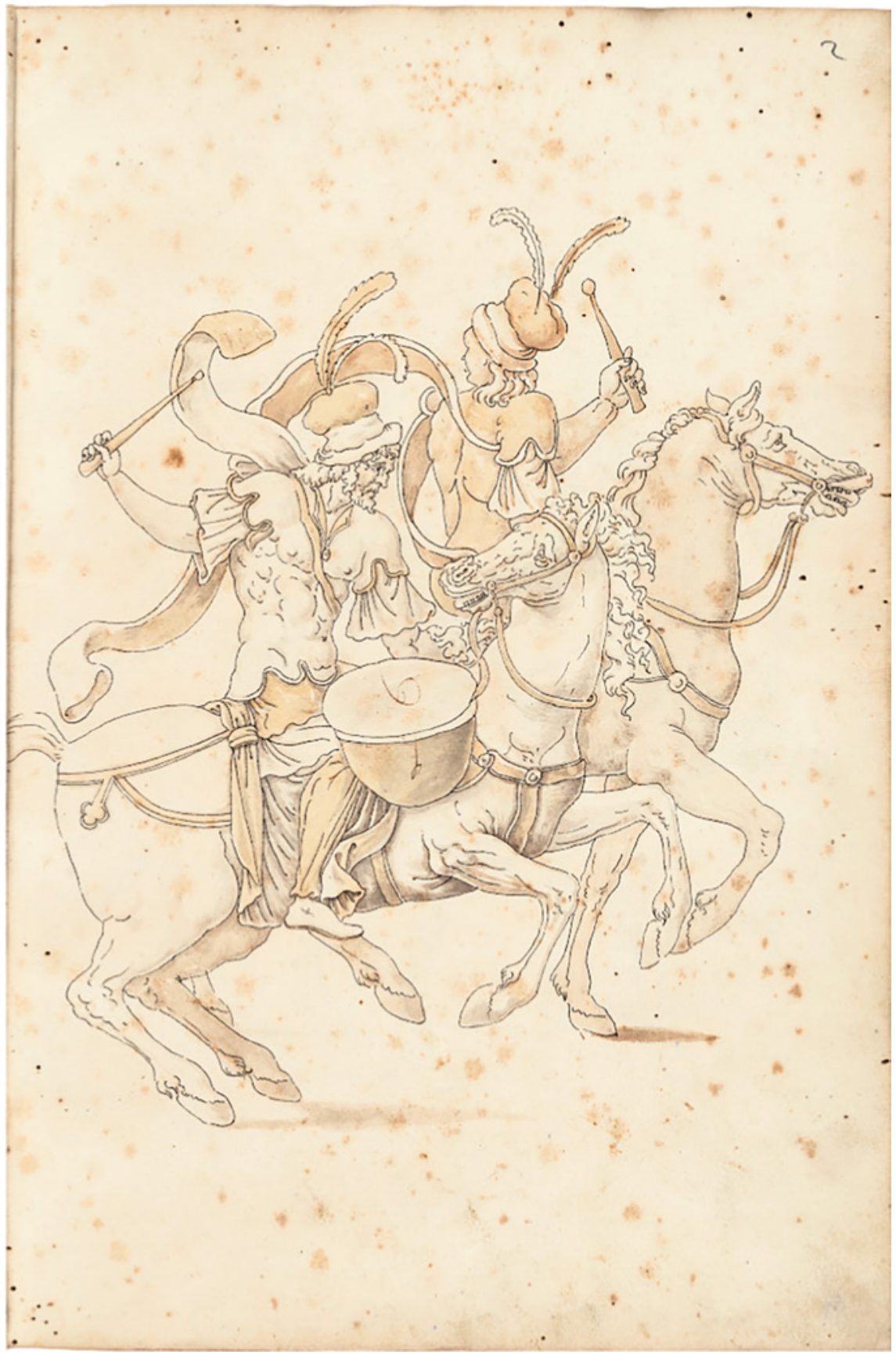

FIGURES 4.20-4.22 Workshop of Jacopo Strada, designs for festival costumes: two tympani players on horseback; a female figure on foot, and a female figure on horseback; Dresden, Kupferstich-Kabinett, ms. CA 93. fols. 2, 80 and 6. 

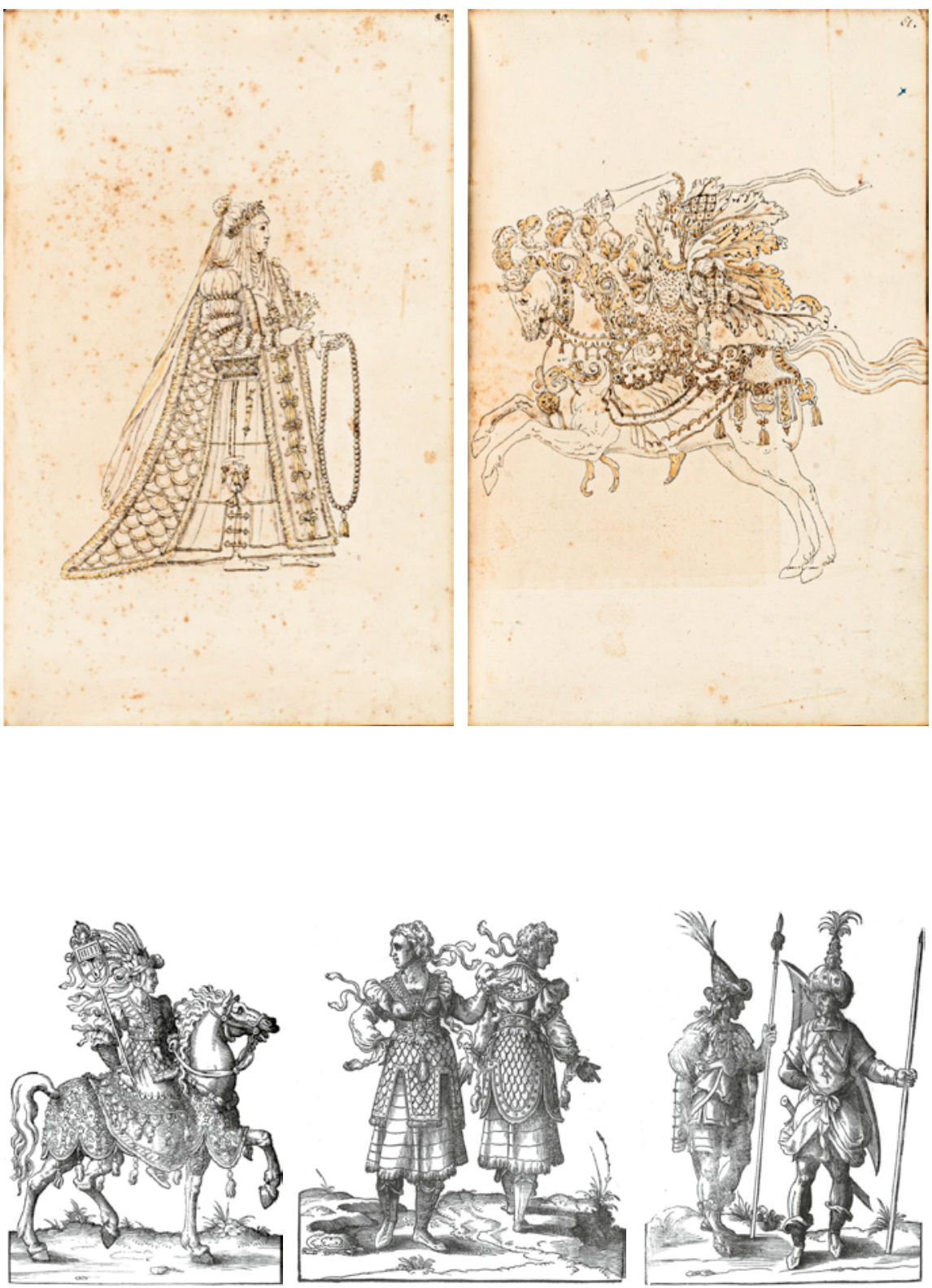

FIGU RES 4.23-4.25 Jost Amman, Europa, Moorish woman and Persian soldiers, engravings after Jacopo Strada's costume designs in Amman's print series Stattliche Mummereien so vor zeiten grosse Potentaten gehabt haben, 1584 . 
how far Jacopo Strada himself was involved in this project: in his testament he accuses Ottavio of having commissioned these engravings without his authorization. But a letter from Ottavio to his father exists which appears to contradict this. Written from Nuremberg, where Ottavio was supervising the printing of some of his father's planned editions, it implies that Ottavio had discussed the project with his father, and that the elder Strada, even if he had not taken the initiative, did not disapprove of it at the time. ${ }^{87}$ In fact he must have approved of it, since the fifth item in a copyright privilege conceded to Strada by Maximilian II in May 1574 bears the same title as the Dresden album, confirming that this or a similar volume is the book Ottavio referred to. ${ }^{88}$

Ottavio incited his father to have the 'mascare' printed because 'he knew that they would sell well', and advised his father to write the accompanying descriptions as soon as possible and have them translated into Latin. Ottavio then would take care of having them translated into German and French. Ottavio's optimism as to the success of this multilingual coffee-table book was probably based on the idea that many of the participants in the prestigious festivities it documented would wish to acquire a copy.

There can be no doubt that Amman's engravings were made for this project, which never materialized as planned by Ottavio. Whether this is due to his father's opposition or for other reasons cannot now be determined. ${ }^{89}$ But what we do know is that Strada disposed of at least two hundred designs for various courtly festivities, as well as of the inside information necessary to write the accompanying descriptions - both indications that he himself had been closely involved in their preparation. This supposition is further corroborated by his connection, likewise documented in Ottavio's letter, with the humanist and draughtsman Giovanni Battista Fonteo, responsible for the cartels and other texts of the festivals designed by Arcimboldo.

Strada's contribution was based on his antiquarian expertise and the visual documentation he had collected in his Musaeum, witness a manuscript presenting hundred designs of 'Ancient helmets and crests as were used of old by the Greeks and the Romans and also by other peoples both in spectacles

87 DOC. 1574-12-05; text transcribed in Appendix A; it will be discussed in greater detail in chapter $14 \cdot 3$.

88 DOC. 1574-05-30; cf. the title of the Dresden volume, Kupferstichkabinett Ca 93, cited above, note 84; moreover the presence of 'satellites', attendants on foot dressed to correspond to the individual equestrian figures, tallies both with the Dresden drawings and with the descriptions of such festivals.

89 In his ambitious publishing programme the elder Strada probably set other priorities; on this, and his conflict with Ottavio, see below, chapter 14. 
and public games, as in war' [Fig. 4.26]..$^{90} \mathrm{~A}$ few of these drawing may derive from ancient coins or monuments, but they also include helmets reminiscent of medieval armour (fols. 30/28, 31/29, 39/37, 45/43, 79/77) [Fig. 4.30], as well as turbans or headdresses inspired by the Turks and other oriental peoples (fols. $21 / 19,37 / 35,48 / 46,63 / 61,65 / 67$ ) [Fig. 4.31]. But most of them are extravagant and fanciful mannerist designs, helmets 'all'antica' intended for contemporary use in jousts and other festivities, rather than as antiquarian documentation (fols. 81/79-90/88) [Figs. 4.27 and 4.29].

Strada did not limit himself to the headpieces included in the Galearum antiquarum, as is clear from the festival drawings in the miscellaneous third volume, which include a few designs for other separate elements of such costumes, such as the leg-piece of a suit of armour and elements of horse's trappings [Figs. 4.32-4.34]. ${ }^{91}$

Like Strada's libri di disegni filled with ornamental vases, the drawings in $\mathrm{Ga}$ learum antiquarum were based on more or less contemporary designs which were part of the material in his collection, such as the vase designs by Giulio Romano. Thus the one drawing which I have found to date corresponding to
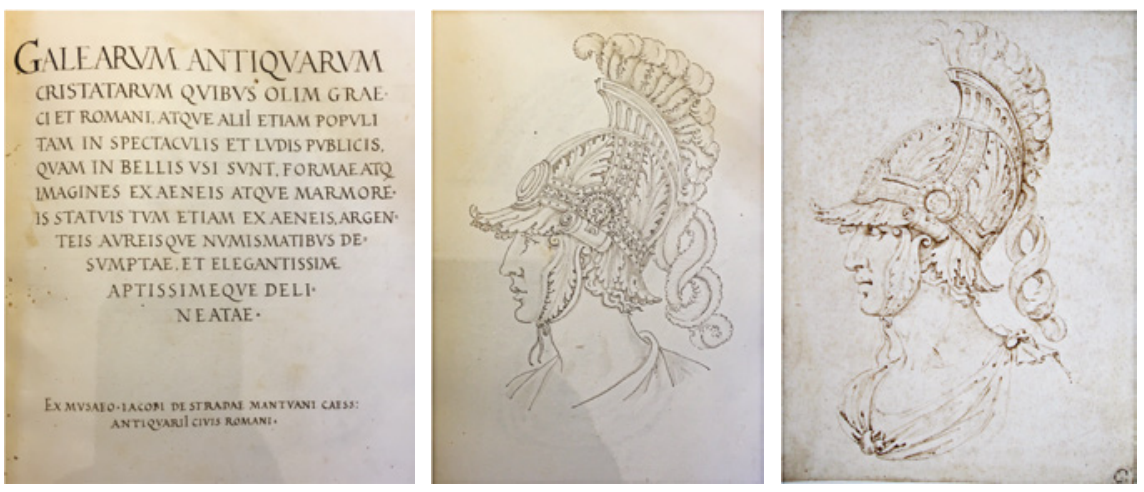

FIGURES 4.26-4.27 Workshop of Jacopo Strada, Galearum antiquarum: title page and the documentary drawings of a design for an ornamental helmet in the antique manner; Vienna, Österreichische Nationalbibliothek, Cod. min. 21, 1, fols. 1 and 33 .

FIGURE 4.28 Anonymous, design for an ornamental helmet in the antique manner, which is the probable source for the drawing in Srada's Galearum antiquarum; New York, private collection.

9o Galearum antiquarum cristatarum quibus olim Graeci et Romani, atque alii etiam populi tam in spectaculis et ludis publicis, quam in bellis usi sunt, formae atque imagines ex aeneis atque marmoreis statuis tum etiam ex aeneis, argenteis aureisque numismatibus desumptae, et elegantissimae aptissimeque delineatae. Ex Musaeo Jacobi de Stradae Mantuani Caess. Antiquarii civis Romani, ÖNB-HS, Cod. min. 21,1; the material is preserved together with other material from Strada's workshop, including the festival drawings. ÖNB-HS, Cod. min. 21,3, fol. 343/6o; fols. 333/50 and 334/51. 

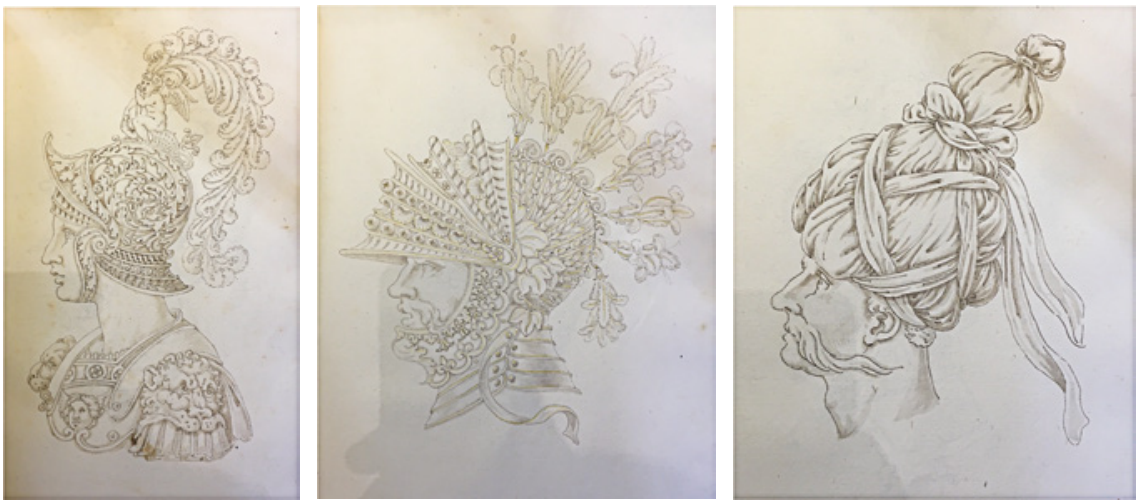

FIGURES 4.29-4.31 Workshop of Jacopo Strada, documentary drawings of designs for helmets and headdresses in antique, medieval, and oriental fashion, from Galearum antiquarum; Vienna, Österreichische Nationalbibliothek, Cod. min. 21,1, fols. 44, 84 and 61 .
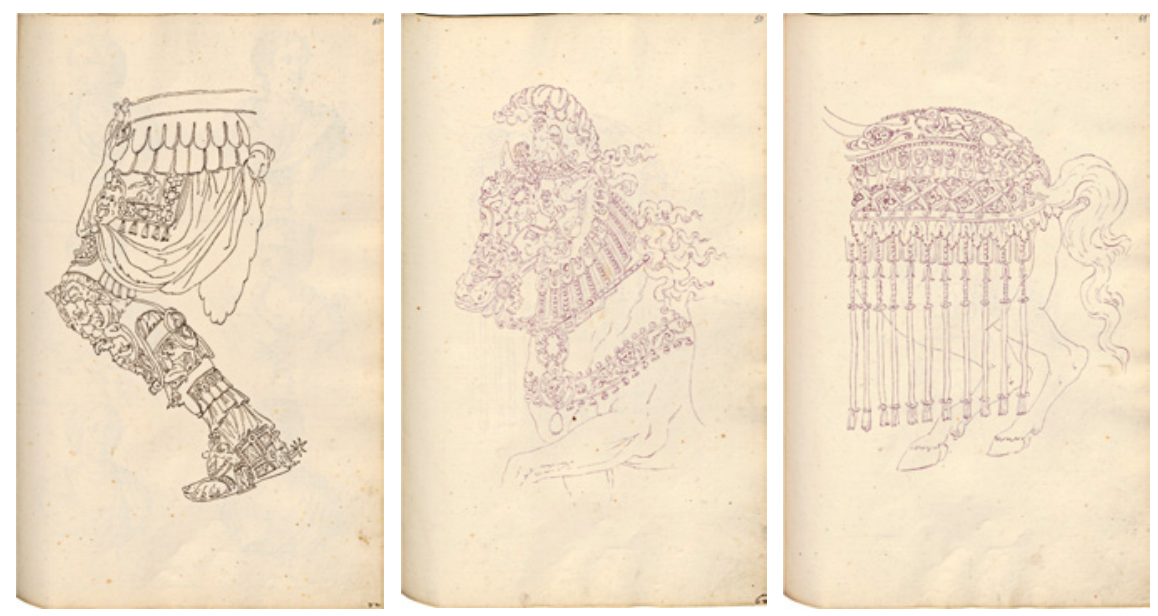

FIGURES 4.32-4.34 Workshop of Jacopo Strada, documentary drawings of designs for a leg-piece of a suit of ornamental armour and for elements of horse's trappings; Vienna, Österreichische Nationalbibliothek, Cod. min. 21, 3, fols. 60,50 and 51 .

one of the designs in the Galearum antiquarum, and probably its source, seems not to be in Strada's own hand [Fig. 4.27 and 4.28]. ${ }^{92}$

Nevertheless a recent find by Zoltán Kárpáti demonstrates that Strada, in addition to the dressed-up elephant, did indeed provide his own designs for some of the festivals at court. Two drawings in the Szépművészeti Múzeum in

92 Private collection, New York. I am grateful to Monroe Warshaw for having drawn my attention to this drawing and for having provided me with a reproduction. 

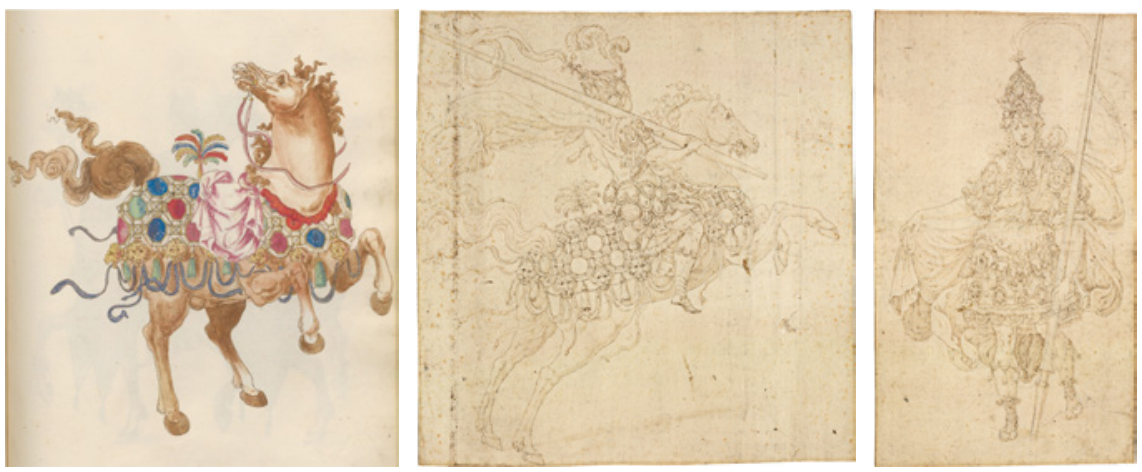

FIGURE 4.35

Workshop of Jacopo Strada, documentary drawing of the design for a richly caparisoned horse, Vienna, Österreichische Nationalbibliothek, Cod. min. 21, 3, fol. 45 .

FIGURES 4.36-4.37 Jacopo Strada, costume designs for two participants in a court festival, Budapest, Szépművészeti Múzeum.

Budapest can be linked immediately to Strada's documentary festival drawings in Vienna. They represent a knight or prince in a richly dressed costume 'alla Romana', wearing a high, plumed hat or turban, carrying a jousting lance and riding a richly caparisoned rearing horse; and a similar-though not exactly identical — figure on foot, of indeterminate gender: it might either be a young man or a goddess or Amazon. ${ }^{93}$ Though seen from a different angle, the horse's trappings are identical to that of a rearing horse (without rider) among the Vienna drawings and, as Kárpáti points out, technique and style of the draughtsmanship are very close: comparison with other Strada material, such as his numismatic drawings, demonstrates their common origin in his workshop. But the Budapest drawings, one of which is drawn on two pieces of paper pasted together, are of much higher quality, more spontaneous: in contrast to the Vienna drawings they are closer to the original sketches: possibly they are the original designs intended to be submitted to the patron's approval and for the subsequent execution of the costumes. A cursory comparison of the photograph with Strada's earlier title pages and numismatic drawings strongly suggests that it is autograph-if so, it is a precious help in better characterizing Strada as a draughtsman, as well as a welcome confirmation of his role in the Vienna court festivals. ${ }^{94}$

93 Budapest, Szépművészeti Múzeum, inv. nrs. 1312 and 1313; Kárpáti 2012. The costume in inv.nr. 1313 is richly set with huge gems, probably cut in glass or rock-crystal, reflecting Pighius's description (Pighius 1585, p. 185). Both inventions are also included in the Dresden albums (Ca 93, fol. 53; Ca 94, fols. 8, 12 and 22). (London, British Museum, Franks II, fol. 117, no. 505) has plausibly been associated to 
In addition to costume designs, it is perfectly possible that Strada, as a court-architect, also provided designs for the ephemeral decorations providing the backdrop to such festivities. A good example of this is the design for a triumphal arch preserved together with the Vienna festival drawings [Fig. 4.38]: both because of its context and its technique and draughtsmanship it can be attributed to Strada or his workshop. Its resemblance to Strada's drawing of a coin-reverse showing a triumphal arch in the Forum of Augustus demonstrates the close connection between antiquarian studies and festival designs of the period [Fig. 4.39]. ${ }^{95}$

Though there is no formal document establishing Strada's share in the preparation of the festivals at court, the circumstantial evidence summed up here is sufficient to warrant the assumption that he did regularly collaborate on these in many ways - as a source of ideas and iconographic information, perhaps as a coordinator and supervisor of the execution, and certainly also as a designer. Research into festivals at the Imperial court should take this into account, certainly as from his arrival at court in about 1559, at least until the
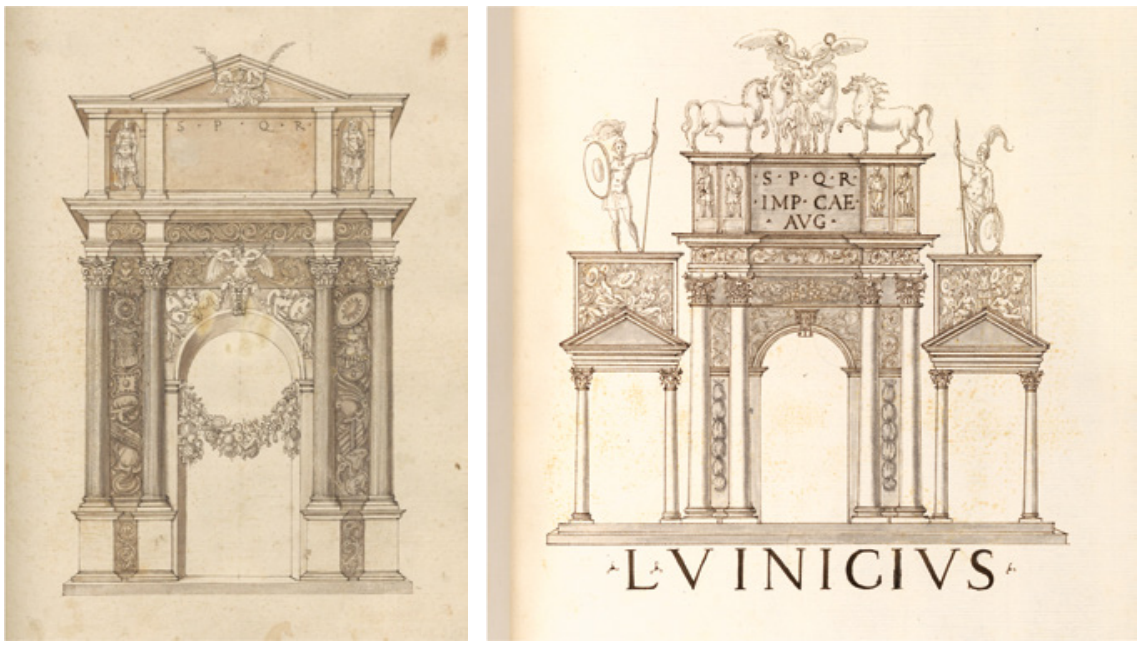

FIGURE 4.38 Jacopo Strada or assistant, documentary drawing of the design for a triumphal arch for a ceremonial entry; Vienna, Nationalbibliothek, Cod. min. 21, 3, fol. 40.

FIGURE 4.39 Jacopo Strada, drawing of the reverse of a coin of Augustus, in his Magnum ac Novum Opus; Gotha, Forschungsbibliothek, ms. Chart-A 2174, vol. 4, fol. 89 r.

Strada's activities as a festival designer by Simon Pepper (in Davies/Hemsoll 2013, II, pp. 662-663, nr. 303); similar, though not identical designs also in the Dresden albums (Ca 93, fols. 63 and 92).

95 ÖNB-HS, Cod. min. 21,3, fol. 323/40. I have not attempted to identify the particular entry for which it was intended. The coin drawing in the Magnum ad Novum Opus, Gotha, Forschungsbibliothek, ms. A 2175-4, fol. 89r. 
death of Maximilian II. An element in Hans von Francolin's Thurnierbuch, a description of the festival organized by King Maximilian for a Habsburg family meeting in Vienna in 156o, suggests that Strada had been involved: it contains an emblematic print and rhyme which, referring to poverty which inhibits the aspiring youngster to reach for higher things, was clearly intended as a bid for patronage [Figs. 4.40-4.41]. This quickly sketched engraving is signed with a monogram consisting of the letters I, $\mathrm{S}$ and a smaller $\mathrm{R}$, which can be read as 'Iacobus Strada <civis> Romanus. ${ }^{96}$ Both the style and the sketchy character of the print, contrasting with the huge illustrations by professional engravers such as Hans Sebald Lautensack and Francesco Terzio elsewhere in the book, suggest that it was a small service which Jacopo had rendered his colleague, as a sequel to their collaboration in the festival itself, in which Francolin, as Imperial Herald, in any case had been closely involved.
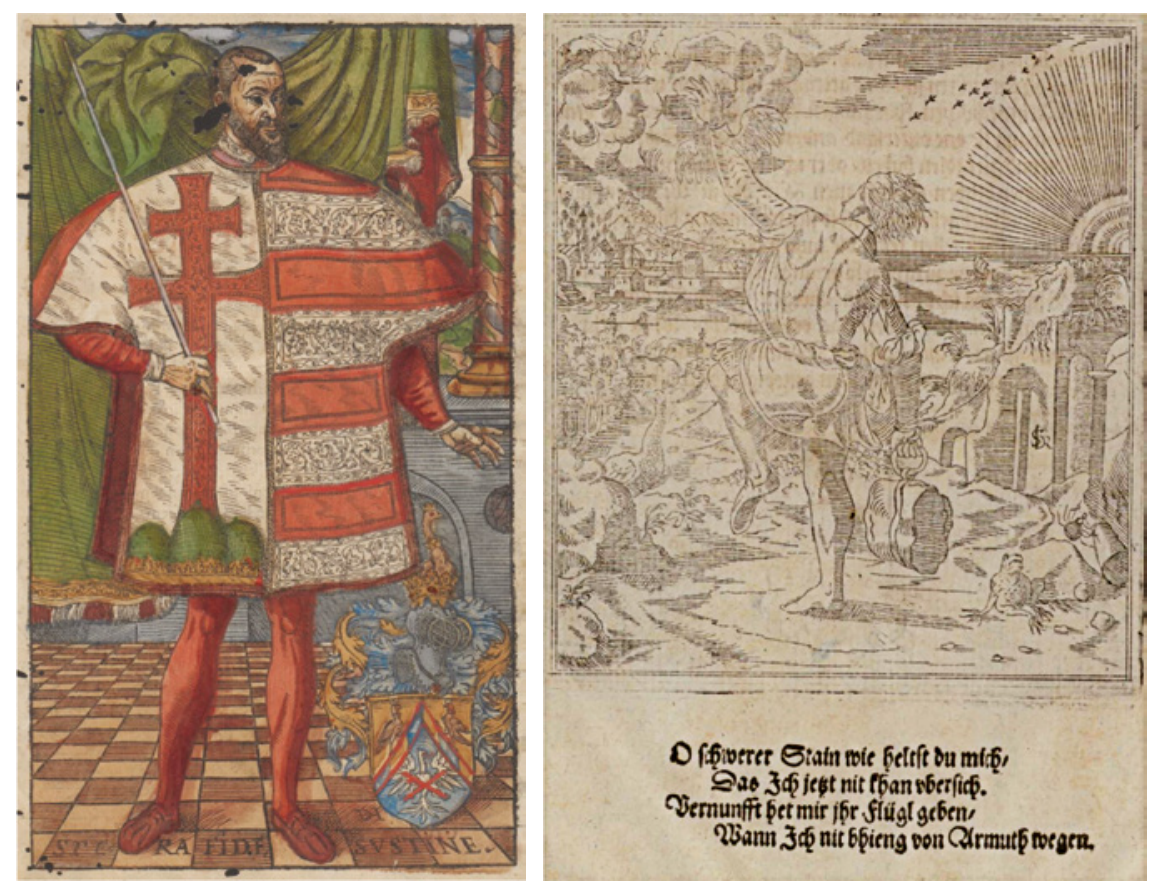

FIgURES 4.40-4.41 Portrait (by Francesco Terzio?) of, and his emblem, here attributed to Jacopo Strada, for the Imperial Herald Hans Francolin in his Thurnier Buch: Warhafftiger Ritterlicher Thaten, describing the festivities organized in Vienna in June 1560.

96 Francolin 1561, Frontispiece; it is already included, with a Latin verse, in the earlier Latin edition (Francolin 1560). 
On the other end of Strada's courtly employment, in November 1579, stands the smaller festivity organized by some noblemen for the younger sons of Maximilian, Archdukes Maximilian and Albert. According to a letter by Sigmundt von Hochenburg to Archduke Matthias, after a pleasant day of sport (running at the ring) the younger Archdukes and a select company of courtiers and ladies were offered an entertainment consisting of a banquet and a dance, and 'ein schöne Mumerey': a beautiful masque. Since this entertainment was organised in Strada's house, he must have been involved in its organisation and he may have provided the costumes for the masque. ${ }^{97}$

\subsection{Indirect Sources Throwing Light on Strada's Employment at Court}

\subsubsection{The Letter to Archduke Ernest}

Though there are few documents that directly link Strada to specific commissions, a number of indirect sources help to draw at least a more general picture of his role in what might anachronistically be termed the cultural policy of the Imperial court. The principal of these is a summary of his tasks given by Strada himself in a letter to the Archduke Ernest, dating from 1579, when the Archduke was acting as Rudolf II's lieutenant in Austria. ${ }^{98}$ In this letter Strada explains the reasons why he had resigned his functions at court, and sued for the Archduke's patronage, listing the various ways in which he had served Maximilian, and hoped to be of use to his son. It is worthwhile to transcribe it in extenso:

Most Serene Prince! I have served twenty-five years here at court, and I have served three Emperors, the Majesties of the grandfather, the father and the brother of Your Highness. The reason why I have resigned [my functions] is that his Imperial Majesty does not employ me in his building projects, and neither in having me prepare books of drawings <libri di dissegni > nor in other things, as did His Majesty your father, who made me work continuously.

So I beseech your Most Serene Highness that, should he wish to employ me in any project involving the art of design ['l'arte del dissegno'], I can serve him very well; and should Your Highness choose to have built a beautiful palace in the manner of Rome or Naples, in a beautiful style and order of architecture; and providing it with beautiful gardens, fishponds, fountains and other delights suitable to a great prince such as

97 DOC. 1579-11-17, letter of Sigmundt von Hochenburg to Archduke Matthias.

98 DOC. $1579^{-0} 5^{-00 .}$ 
Your Highness, I can serve him extremely well, and what I will have had made will be praised by every man of taste ['hogni huomo di giuditio'].

I can also serve in having made designs ['inventioni'] for masques, jousts and other nice things such as one day may occur to Your Highness. Also if he should wish to make a beautiful cabinet of antiquities and medals, I will serve him in that as well. Should he wish to set up a most beautiful library of all sorts of books, also in that I will be able to serve him. In many things I can serve Your Most Serene Highness, which would take too long to mention all, and perhaps as well as any man in Germany and Italy.

This letter is of paramount interest as an indication both of Strada's actual employment by Maximilian II and of his own perception of it. In interpreting it, many things should be taken into consideration. Strada doubtless either presented his request in person or through one of Ernest's courtiers, most probably his own elder son Paolo, who had been appointed one of Ernest's gentlemen of the chamber. In fact the Archduke must have known perfectly well who Strada was, if only because - as we shall see below — he used to frequent Strada's studio in his infancy. The fact that Strada found it necessary to introduce himself in this formal manner perhapsindicates that this official suit for patronage was directed as much at the Archduke's advisers as at his person. This is corroborated by his signature, 'Jacopo Strada, Architetto et Antiquario', including both the official functions he had discharged at court, whereas in all other correspondence he was content with the single appellation of Antiquario dellaSacra CesareaMaestà.

Secondly, it is important that Strada himself states quite clearly that he had been continually employed by Maximilian II. Though it is likely that in this bid for patronage he presented his qualifications in the rosiest light, his claim must be taken seriously: he could not afford to wildly exaggerate his services when - after twenty years of residence in Vienna— these were so well known, or could so easily be checked. It is moreover corroborated by Maximilian II himself: on one of the occasions that his brother-in-law, Duke Albrecht, requested to be allowed to make use of Strada's services, the Emperor replied that he would concede this, 'wiewol ich seiner in etzlichen sachen nit wol geraten khan', 'though in many things I can hardly spare him. ${ }^{99}$ On a second occasion, he reacted irritably to Albrecht's supposition that, because of a projected trip to Bohemia, he would have no need of Strada, and noted that, on the contrary,

99 BHStA-LA 4461, fol. 347v; printed in BIBL 1916-1921, II, p. $5^{\circ}$ (and cited in Lietzmann 1987, p. 116). 
he had intended to employ Strada in that period, and would only allow him this one more trip on the Duke's behalf. 100

'In etzlichen sachen': Maximilian's choice of words implies that Strada's services had been wide-ranging, but the formula Strada uses in his letter to Archduke Ernest suggests that the most important had been his involvement in the Emperor's architectural projects and his manufacture of libri di dissegni: it is tempting to relate these to Strada's respective functions of architect and antiquary. The precise character of these services is further specified in the list of capacities in which Strada offered to serve the Archduke. These can roughly be divided into two categories. Doubtless it is largely due to Titian's portrait that Strada has been often presented as a more-or-less commercial dealer in art and antiquities: his offer to help the Archduke to set up 'un bel studio di antiquità et medaglie' and a 'bellissima libraria di hogni sorte de libri' seems to fit this image. Much less attention has been paid to Strada's own artistic endeavour; yet for Strada this seems to have constituted his principal claim to patronage. Certainly no mean pretension, to claim that he can serve the Archduke 'in qualunque cosa dove introvenghi l'arte del dissegno'. Clearly where Strada refers to libri di dissegni, he means books of drawings, drawings documenting 'designs' or 'inventions', but also in themselves examples of graphic art: and we have seen that he did indeed purvey these to his Imperial patrons. But when he here speaks of the 'arte del dissegno' it is evident that he refers to the sketch, the design, the 'invention', the concept or plan even, rather than to any specific product of the pen or pencil. As particular examples of his competence he mentions the design of architecture and architectural decoration, and of 'inventions' for court festivities.

But perhaps the most important indication of the character of Strada's service in this field lies hidden in two tiny phrases: 'quello ch'io farò fare sarra laudato da hogni huomo di giuditio' and 'posso anche servire in far fare inventioni per mascherate' [italics mine]. 'Far fare' rather than 'fare', that is 'to have made', rather than 'to make': what he intended to provide would be actually prepared by others. Strada appears to have viewed his exercise of the arte del dissegno as a mental, rather than a manual process: he intended to provide materials that he had not necessarily produced himself, but which he had 'invented' and then commissioned others to execute, though he would closely supervise their work and explicitly reserved both final artistic responsibility and possible merit to

100 HHStA, Familienkorrespondenz A, Karton 2, fol. 320-321; cited in Lietzmann 1987, p. 117 and notes 99-100. Fugger warned the Duke not to impose too much on the Emperor's courtesy, in case he might refuse to let Strada come when needed most in Munich: Fugger to Duke Albrecht v of Bavaria, 5 March 1569, quoted in Von Busch 1973, pp. 128-129. 
himself. Basically he proposed to mediate between patron and executive artist, thus outlining a role closely resembling the function of 'sopracapo' he had envisaged for himself more than twenty years earlier when involved in Archduke Ferdinand's silver table fountain. Such a role fits in well with the type of consultative capacity that has been outlined in the preceding paragraph.

\subsubsection{Strada Employed by Duke Albrecht $v$ of Bavaria}

There is no indication that Strada's offer to Archduke Ernest was accepted. On the other hand it is known that Strada did occasionally work for other patrons. Strada's work for Duke Albrecht V of Bavaria, to whom he was delegated three times, is perhaps the best documented and best published aspect of his career. Since this is the only instance of Strada's prolonged employment by a princely patron other than the Emperor, a comparison may shed some further light on his activities in Vienna.

The principal reason for Strada's call to Munich, at the advice of Hans Jakob Fugger, was the Duke's wish to bring together a collection of antique sculpture, and in his three trips to Venice Strada did indeed manage to acquire the bulk of the collection of the patrician Andrea Loredan, important both for its size and its quality. He also bought some further antique statuary and negotiated unsuccessfully for the acquisition of two well known collections of ancient coins, cameos and intaglios. His final account, however, also makes mention of a number of miscellaneous objects intended for the Duke's Kunstkammer, including statuettes, paintings and drawings and objets d'art; the latter included a valuable casket in rock-crystal, precious stones and enamel intended to be given by Duke Albrecht's heir to his prospective bride. But he also had provided a considerable quantity of books, probably manuscripts, and over the years his workshop provided many libri di disegni.

This indicates that Strada was prepared to cater to the needs of the three principal components of the impressive complex of collections instituted by Albrecht v:library, Kunstkammer and Antiquarium. His involvement stretched, moreover, beyond the simple acquisition of the objects: he was also concerned in their restoration-engaging and supervising the artists employed-and their eventual placement. His advice in this was in fact deemed of particular importance: Fugger warned the Duke not to abuse the Emperor's benevolence, in case he might refuse to grant leave to his faithful antiquary when the arrangement of the sculpture would be determined.

It is clear that Strada's role in Munich far exceeded that of a simple agent or intermediary: with Fugger's, his was the leading spirit in the conception at least of the Munich Antiquarium, and very likely of the complex of collections as a whole. His role, moreover, was not limited to consultation: the idea of 
constructing a new, separate building to house both library and antiquitiesthe first true museum north of the Alps, and one of the earliest in Europeappears to have been his. When this idea was adopted, he contributed a concrete proposal, demonstrating his architectural expertise in a careful, elegant and not impracticable Italianate design, which, unfortunately, proved to be beyond the Duke's purse, or his German masons' competence. ${ }^{101}$

\subsubsection{Strada's Bid for Employment by the Elector August of Saxony}

Strada's activities in Munich had been explicitly requested and, it appears, well rewarded. Strada needed such income partly to finance the construction of his house, partly for the editorial projects he undertook from the early $1570 \mathrm{~s}$ onward. Though Emperor Maximilian II did support his projects, he was not willing or capable of providing the large-scale financial backing necessary to realize them, which may have been the reason that, shortly before his death, he allowed Strada to apply to one of his best friends and allies in the Empire, the Elector August of Saxony. Early in September 1576, when presiding the Diet at Regensburg, he wrote to the Elector to inform him that Strada intended to come to Saxony, 'um sich daselbst in baumeisterei und andern kunstreichen sachen daran Dero Liebden ungeurlich lust und gefallens tragen mochte geprauchen zu lassen': 'in order to be employed in architecture and other artistic endeavours in which your worship takes such extraordinary interest and pleasure'. By this time Maximilian appears to have been more willing to let Strada go, perhaps merely to enable him to obtain funds useful in the realization of the projects of his antiquary - which after all would increase the prestige of his court.

On the other hand it is possible that his financial resources did no longer allow the Emperor to undertake the type of project in which Strada's expertise could be profitably employed: he would be happy to secure for his faithful servant some other opportunity to exercise his talents. It is remarkable that Strada is recommended for his artistic rather than for his scholarly capacity, probably because this corresponded most with August's own interests. From the few documents available it appears that Strada undertook his trip to Saxony at his own initiative, rather than at the Elector's invitation, and there is no evidence that his offer was accepted.102

\footnotetext{
101 On Strada's acquisition for the Duke of Bavaria and his concept and designs for the Munich Antiquarium, see below, Chs. 8 and 12.3.

102 Lietzmann 1987, pp. 129-130. Strada had already visited Elector August in person, at Annaburg in or before 1574, when he lent him a book with drawings of Roman Imperial portrait busts, in order to have it copied; both the original and the copy are still preserved in the Dresden Kupferstichkabinett (Ms CA 74) and the Sächsische Landes- und Universitätsbibliothek Dresden, Ms. Mscr.Dresd.App.187; cf. JansenMetze (forthcoming).
} 


\subsubsection{Private Patrons}

Finally some reference should be made to other patrons who made use of Strada's services: these were never as comprehensive as those rendered to the Emperor or the Duke of Bavaria. His activities on behalf of Hans Jakob Fugger have been already discussed in detail: Strada's erudite, numismatic studies were encouraged and sponsored, though perhaps not explicitly commissioned by Fugger, in contrast to the production or acquisition of objects for his collections: libri di disegni (including the results of Strada's research, in the first place the numismatic corpus), books and maps for his library, antiquities and, occasionally, contemporary works of art for his studio. There is no concrete indication that Strada was involved in any architectural or decorative project of Fugger's, whose artistic patronage is ill documented, and may not have been as extensive as that of some of his relatives. What is particularly remarkable is the close and cordial relationship existing between patron and client, tending towards the partnership of those sharing absorbing interests, rather than that of master and servant.

Strada's relationship with the Bohemian magnate Vilém z Rožmberka must have been of considerable importance: in a letter of 18 December 1573 Strada refers to 'die alte kundschaft'. It certainly included the supply of objects for Rožmberk's library, to wit a drawing of the complete spiral frieze of the Column of Trajan in Rome, mounted on four long paper scrolls housed in a small cabinet, and a manuscript copy of Strada's eleven-volume description of ancient coins, the A.A.A. Numismatwn Antiquorum $\Delta \iota \alpha \sigma x \varepsilon v \varepsilon$. In view of Strada's dedication to Rožmberk of his edition of Serlio's Settimo libro it is very tempting, however, to assume that he had also been involved in his patron's architectural projects, most likely his palace in the precincts of the royal castle, the Hradčany, at Prague. ${ }^{103}$ In 1583 Strada visited the Moravian nobleman Jan Šembera Černohorský z Boskovic at his castle at Bučovice, where the sumptuous decoration of a suite of small rooms, a typical studiolo ambiente, was in course of execution [below, Figs. 10.16-10.22]. Though again it cannot be definitely proved,

103 DOC. 1573-12-18; Serlio 1575, dedication. Rožmberk's commission of the version of the $\Delta 1 \alpha \sigma \kappa \varepsilon v \varepsilon \varepsilon$ in the Czech National Library in Prague is demonstrated by the initials W R (Wilhelm von Rosenberg) on the title pages, combined with its provenance from the Jesuit college in Český Krumlov, Rožmberk's principal residence. Strada's connection with Rožmberk is discussed in greater detail below, Ch. 10.3. Another possible link between Strada and Rožmberk is suggested by the material on various waterworks, such as fountains, watermills, pumps etc. which Strada brought together and were published by his grandson in various editions in the early seventeenth century; these might have been useful to Rožmberk who derived a considerable proportion of his revenue from the immense artificial fishponds at his domain at Třeboň in Southern Bohemia; cf. Jansen 2002, 50-51 (in Italian) and pp. 222-223 (in English). 
it is very likely that Strada was involved in the planning and the design of the decoration of these rooms, in addition to supplying some of their contents. ${ }^{104}$

\subsection{Conclusion}

Taken together, the summary of the services Strada had rendered at the Imperial court as given in his letter to Archduke Ernest, and his similar activities for other patrons as known from other sources, allow the conclusion that his concrete tasks at court did exceed those few that are documented. In view of Strada's unique artistic and antiquarian expertise it can be assumed that he was kept abreast of Imperial commissions in these fields and was expected to tender his advice even when he was not formally requested to do so. More explicit contributions will have been rarer, though even these must have largely exceeded the documented instances. In these cases Strada appears to have limited himself to provide the 'invention' for projected commissions and the subsequent supervision of their execution. But he rarely—if ever-executed them himself; his part in such commissions would therefore not be registered in the accounts.

One should, on the other hand, be as wary of overestimating as of understating the time Strada spent on, and the degree of attention he paid to such commissions. The fact that he could often concentrate on projects of his own-first the construction of his house, later his scholarly projects-and that he was able to work regularly and for extended periods for other patrons, shows that he was not continually employed in Imperial projects. In October 1562 Strada briefly related his personal affairs in a letter to Bernardin Bochetel, Bishop of Rennes and French ambassador to Ferdinand I, in terms suggesting little pressure from the part of his patrons:

$<\ldots>$ as to myself and my family: we are all well, and I have become the complete philosopher, and always stay at home and occupy myself with having built my little house $<\ldots . .>.^{105}$

Yet the evidence is sufficient to warrant an attempt to sketch Strada's activities for his Imperial patrons more fully. It is obvious to begin this sketch with the function in which he was first appointed and for which he was best paid, that is his function as an Imperial Architect. This will be the subject of the next chapters.

104 Cf. below, Ch. 10.4.

105 DOC. 1562-10-21: 'di me et casa mia: tutti stiamo bene, et son del tutto fatto Philosopho, et sempre mi sto in casa et atendo a far batir la mia picciol casa'. 